\title{
UNDERLYING LOW TONES IN RUWUND
}

\author{
Jay A. Nash \\ Catholic Relief Services
}

\begin{abstract}
In this paper the author examines data from Ruwund, a language with surface tone patterns often the reverse of those reconstructed for ProtoBantu, and proposes that, whereas most contemporary Bantu languages are believed to have tonal systems based on an underlying high/toneless contrast, Ruwund is based on a low/toneless contrast. Rules of tone spread and deletion apply to low tones rather than high tones, and the "default low insertion" rule of other languages is replaced in Ruwund by a rule adding default high tones. This finding is theoretically significant in that it contradicts Pulleyblank's [1986] proposal that "low" is always the default value in a two-tone language.
\end{abstract}

\section{Introduction*}

Since the mid 1980's various tonal data have been elegantly explained through analyses which combine an autosegmental approach to phonology with underspecification theory. In underlying representations, the various tone-bearing elements of a morpheme are viewed as either bringing tones to the tonal tier (i.e., as being tonally specified) or as making no tonal contributions (i.e., as remaining tonally unspecified). The underlying tones may be linked by association lines to the

\footnotetext{
* The Ruwund data presented here were collected in Musumb, Zaire, from Cimwiish Nawej, Diitend Mutamb, Yaav Cisambu and Matepu Mwaan-a-Mweñ. The Ciluba data were provided by Kazambu Kasonga and Nkundu Ndjey of Mbuji Mayi, Zaire. I am also indebted to Zoann Branstine, Mary Clark, Laura Downing, John Goldsmith, Larry Hyman, Charles Kisseberth, and Martha Wright for having read portions of this paper at various stages in its evolution and contributed many useful comments. Claude Stampa provided invaluable technical assistance.
} 
elements of the segmental tier to which they belong or they may come in a "floating" (i.e., unlinked) form. The tones may spread, move, or interact with each other according to ordered, language-specific tone rules. At some point in derivations, a general rule applies which assigns a default tonal specification to all tone bearing units which as yet remain unlinked to any tones.

The autosegmental/underspecification synthesis has proven particularly useful in characterizing the spreading and shifting of tones in a number of languages of the Bantu family. 1 One characteristic shared by virtually all recent autosegmental studies of Bantu languages is that high $(\mathrm{H})$ tones are viewed as being underlying, and low (L) tones as being inserted by a default rule. ${ }^{2}$ The $\mathrm{H}$-based approach seems justified in that high tones rather than low tones are affected by basic tone rules and figure in the conditioning environments of these rules. It is also consistent with Pulleyblank's [1986] claim that in two-tone languages, L must be the default value.

In her analysis of Igbo, Clark [1989] challenges the view that in languages with two-way underlying contrasts, $\mathrm{H}$ is always the underlying tone and $\mathrm{L}$ the default value, by showing that an approach in which $\mathrm{L}$ is viewed as underlying more satisfactorily accounts for the data of that language. In the present paper, I will argue that at least one member of the Bantu family - the Ruwund language of Zaire and Angola ${ }^{3}$-is also L-based and, counter to Pulleyblank's proposal, makes use of a default-H rule. Low tones, rather than high tones, will be seen to participate in such common Bantu tonal phenomena as tone spread and adjacent tone deletion, and high tones, rather than low tones, will be found in non-definable "elsewhere" locations. The Ruwund data, therefore, support Clark's conclusion that underspecification theory must allow for L-based systems, though perhaps regarding them as "marked".

That an occasional Bantu language would be found where $\mathrm{L}$ is the underlying value and $H$ the default value should not be surprising. The family is famous for complex tonal systems in which underlying tones move to new locations during the

1 See Pulleyblank's [1986] analysis of Tonga for an example of tone shift, and Goldsmith, Peterson and Drogo [1989] for an example of tone spread.

2 Botne's [1991] analysis of Ciruri is exceptional in that it proposes underlying low tones in verbs. It should be noted, however, that as Botne's account simultaneously makes use also of underlying high tones and underlying "accents", it represents a much more significant departure from a standard autosegmental/underspecification approach than that offered here for Ruwund.

3 Ruwund, which is spoken in two major pockets along the Zaire-Angola border, appears in scholarly literature under a variety of names, including "Lunda", "Luwunda", "Luunda", "Ruund", "Uruund", "Northern Lunda", and "Lunda of Mwant Yav". It is language L53 (Luwunda) in Guthrie's [1948] classification system, and K23 (Ruund) in Bastin's [1978]. Speakers of Ruwund, who call themselves Aruwund, refer to the language as Uruwund (of which the initial syllable is a nominal prefix). It should be noted that Ruwund is distinct from "LundaNdembo" (Guthrie's L52 "Lunda" and Bastin's K22 "Ndembo"), a language spoken in southern Zaire and northern Zambia which is only a moderately close cousin to Ruwund and not at all mutually intelligible with it. 
derivation of surface forms or are deleted through interactions with other tones. It is, thus, not uncommon for segments which bear high tones at the underlying level to surface with low tones. Clearly, languages such as these where there are significant tonal changes during surface form derivation are ripe grounds for an eventual reinterpretation regarding which tone is "basic" and which is default-inserted. In Ruwund, the potential for reinterpretation was especially great, since Ruwund belongs to a small group of Bantu languages manifesting historical tonal "reversal"- that is, which have surface tone patterns that are, in most cases, the inverse of what Proto-Bantu is believed to have had. Although tracing the evolution of "reversal" and Ruwund's L-based tone system is not the primary goal of this investigation, one possible historical scenario will be offered at the conclusion of the discussion.

\section{Nominal Tone}

To make the case for underlying lows in Ruwund, I will first examine basic tone patterns for nouns in the language and show that an L-based analysis is more economical than various possible $\mathrm{H}$-based ones. This discussion will provide the foundation for an examination of a few critical verb forms where only an underlying low approach adequately generates the data. 4

Nouns are a good place to start an investigation of Ruwund tone since they are morphologically simple, consisting usually of just a nominal prefix and a root. More importantly, Ruwund nouns, unlike verbs in this language, bear lexical tone, and thus permit some revealing comparisons to Proto-Bantu reconstructions and to nouns of other contemporary Bantu languages. Unfortunately, however, a comparison of Ruwund nouns to those of other languages is complicated by the fact that Ruwund is not only a "reversing" language, but one of a belt of Bantu languages where word-final vowels have been dropped, at least in surface forms.

Like most contemporary languages of the family, Proto-Bantu is believed to have used only open syllables. However, all Ruwund nouns, as well as most verb forms, 5 end either in consonants or in an $u$ vowel which is phonetically voiceless and which carries no tone. ${ }^{6}$ For this reason, it is useful to examine first some data

4 Space considerations limit the data discussed to what is essential for the argument, though some additional data is provided at the conclusion of the paper. For a full description of the Ruwund tonal facts-including complete verbal paradigms for all tenses with various configurations of affixes - the reader is referred to Nash [1992].

5 The verbal exceptions include imperatives employing object prefixes, relative forms, and Distant Past tense forms, all of which end in a short, voiced a vowel. For the most part, these are not dealt with here, but an explanation can be found in Nash [1992].

6 Nouns that end in voiceless $u$ have the same tone patterns ( $u$ ignored) as those with no final $u$. Examples include mûtu "head" (like ût "bow"), muntu "person" (like muj "root"), cisaku "disease from sorcery" (like nzal "hunger"), rupwàmbu "bell" (like mukìl "tail"), and kapwâpu 
from Ciluba, a neighboring language which also manifests "reversal", but in which final vowels have been retained.

The five Ciluba noun roots in (1) show clear evidence of "reversal" when compared to their Proto-Bantu reflexes; syllable for syllable, tonal specifications are the opposite in Ciluba from what Guthrie [1971] reconstructed for the protolanguage.

(1) (low-toned vowels have grave accents; high-toned vowels are unmarked) 7

\begin{tabular}{|c|c|c|c|c|c|}
\hline & 'root' & 'bow' & 'hunger' & 'tail' & 'hair' \\
\hline Proto-Bantu & $-d_{1}$ & $-t a$ & -jàdà & -kilà & -cùki \\
\hline Tone melody & $L$ & $H$ & $L L$ & $H L$ & $L H$ \\
\hline Ciluba & $-j \ddot{i}$ & $-t a ̀$ & -zala & -kìla & ì \\
\hline Tone melody & $H$ & $L$ & $H H$ & $L H$ & $H L$ \\
\hline
\end{tabular}

Furthermore, whereas nominal prefixes are reconstructed as low-toned in ProtoBantu, they are high-toned in Ciluba (e.g., mukila 'tail', butà 'bow', mujì 'root').

As can be seen in (2), it is a short step from the Ciluba forms to the Ruwund cognates. (Prefixes have been separated from the roots to facilitate comparison with the forms in (1) above.)

$\begin{array}{lcllll} & \text { 'root' } & \text { 'bow' } & \text { 'hunger' } & \text { 'tail' } & \text { 'hair' } \\ \text { Ciluba: } & m u-j i & b u-t a ̀ ~ & n-z a l a & m u-k i l a & n \text {-sukì } \\ \text { Ruwund: } & m u-j & \hat{u}-t & n-z a l & m u-k i ̀ l & n-s u ̂ c\end{array}$

Tonal melodies for the Ruwund nouns closely resemble those for their Ciluba counterparts. Forms for 'root' and 'hunger' are all high in both languages. The two-syllable H-L sequence of Ciluba butà and nsukì appears instead as a singlesyllable falling tone in Ruwund ût and nsûc. In one case, mukìl 'tail', a contrasting tonal element in the melody appears to have been lost: the final $\mathrm{H}$ of the Ciluba L$\mathrm{H}$ root melody is missing in the Ruwund noun, which ends only in L.

The nouns examined here are not isolated examples, but rather typify correlations between Ruwund, Ciluba and Proto-Bantu. A very large number of reflexes can be found where Proto-Bantu bisyllabic roots with first-syllable highs and

"insect" (like nsûc "hair"). It should be noted as well that a final $u$ vowel, like non-final voiced $u$, causes a preceding $t$ or $d$ to be realized as a retroflex affricate.

7 It is customary in Ciluba grammars and vocabularies to mark low-toned syllables (and contour-tone syllables), while leaving high-toned syllables unmarked (as opposed to the usual practice in Bantu of marking high-toned syllables). "Tail" is thus mukila rather than múkila. As marking lows represents by far the more economical use of diacritics in Ruwund as well, this practice will also be followed in Ruwund spellings. 
second-syllable lows (by far the most common type in Guthrie's reconstructions) have come to have first-syllable lows in both Ruwund and Ciluba, and, in the latter language, second-syllable highs (e.g., R: mashìk C: mashika PB: *-tíkà 'cold';

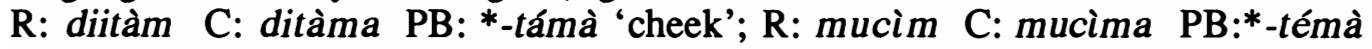
'heart'; and R: diikùm $\mathrm{C}$ : dikùmi $\mathrm{PB}:{ }^{*}$-kómì 'ten'). Also, there are numerous reflexes where bisyllabic roots that were entirely low-toned in Proto-Bantu have become all high-toned in Ruwund and Ciluba (e.g., R: nnam C: nyama $\mathrm{PB}:$ *-yàmà 'animal'; R: diikond $\mathrm{C}$ : dikonde $\mathrm{PB}: *-k$ òndè 'banana'; R: ngomb $\mathrm{C}:$ ngomba PB: *-gòmbè 'cow'; R: ngam C: ngoma PB: *-gòmà 'drum'). Though examples are not numerous, Proto-Bantu low-high melodies for which reflexes can be found typically become high-low in Ruwund and Ciluba (e.g., $\mathrm{R}: m w \hat{o} j \mathrm{C}:$ mwonjt $\mathrm{PB}:{ }^{*}-g o ̀ d i$ 'rope'). Tonal opposition is also usually found in monosyllabic roots (e.g., R: muntu [with voiceless final $u$ ] C: muntu PB: *-ntù 'person' and R: mûtu [with voiceless final u] $\mathrm{C}$ : mutù $\mathrm{PB}:{ }^{*}$-to 'head'). 8

1.1 Preliminaries: End Vowel Rules (EVR) and pre-EVR representations. The Ruwund nouns $m u j$ 'root' and ât 'bow' reveal an interesting problem in Ruwund phonology that must be dealt with before much more can be said about reversal or about the nature of underlying tonal contrasts: what is to be the underlying representation of roots for short, monosyllabic nouns such as these? Consider the following: $-m u$ - of $m u j$ and $u$ - of ût are merely nominal prefixes, presumably having an identical tonal specification at the underlying level. ${ }^{9}$ Since these nouns have different surface tones, the roots $-j$ and $-t$ are necessarily viewed as tonally contrasting. An analysis employing only tone vs. toneless contrasts at the underlying level will thus want, in most circumstances, to consider one of these to be underlyingly tone bearing and the other to be toneless.

Since ût has a surface contour tone (i.e., is a syllable linked to both an $\mathrm{H}$ and an L on the tonal tier) yet also has a short vowel, it is highly likely that the noun's root is in some way moraic. This follows from the fact that without at least two moras in the noun at a pre-surface level in the phonology, it is difficult-in any approach using only a tone/toneless underlying contrast-to generate a two-tone contour,

8 Guthrie also reconstructed a few H-H nouns and roots for Proto-Bantu. Unfortunately, only a handful of these survive in Ruwund and the rare reflexes that can be found often manifest different tone patterns. Proto-Bantu *yitu 'us,' for example, is êtu (with HL melody) in Ruwund, while reconstructed root *-jada 'claw' appears in Ruwund as -zàl (with a low tone on the surface but potentially a LL or LH melody prior to deletion of the final vowel, as explained in section 1.1).

9 Although class 14 prefix $u$ - is realized with a falling tone in ut 'bow, gun,' it is, like mu-, simply high-toned in all polysyllabic nouns (e.g., ujim 'anger,' usând 'adolescence,' ulààl 'bed'). Furthermore, the same tonal contrast can be found in short, monosyllabic nouns employing identical prefixes (e.g., mât 'bows' and maj 'dances,' both of which use class 6 prefix ma-). 
regardless of which tone, $\mathrm{H}$ or $\mathrm{L}$, is taken as being the underlying one. If $\mathrm{ut}$ were to be viewed as having only one mora (that of prefix $u$ ) from the outset, it would be expected that an underlying tone (T), whether brought to the tonal tier by prefix $u$ (as in (a) and (b) below) or by root $t$ (as in (c)), and whether floating (as in (b) and (c)) or linked (as in (a)), would link (or remain linked) to that single mora (as in (d) below) prior to the application of a default tone rule.
(a)
(b)
(c)
(d)

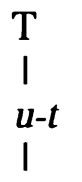
$\mathrm{T}$
would all be
$m$

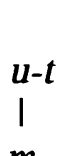
$\mathrm{T}$
$u-t$
I
$m$

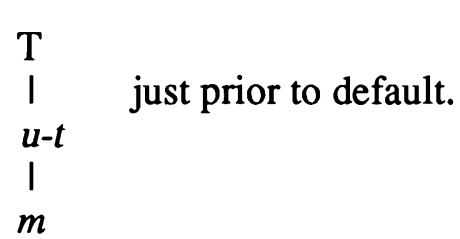

$$
\text { ( } \mathrm{T}=\text { underlying } \mathrm{H} \text { or } \mathrm{L} \text { ) }
$$

There would, thus, be no tonally-unspecified mora remaining at the time of default tone insertion to allow or require the assignment of a contrasting default tone, thereby supplying the second component of an eventual surface $\mathrm{H}-\mathrm{L}$ contour. 10

If the root $-t$ of $\hat{u} t$ must be moraic, and either $-t$ or $-j$ (of $m u j$ ) must be tonebearing, there would seem to be two options: to view Ruwund final consonants as being moraic (at least potentially), or to view Ruwund words as having vowels at the underlying level which (with the exception of $u$ ) fail to surface due to the operation of a deletion rule. In other words, ût, from a segmental standpoint, must have an underlying representation as in (3).

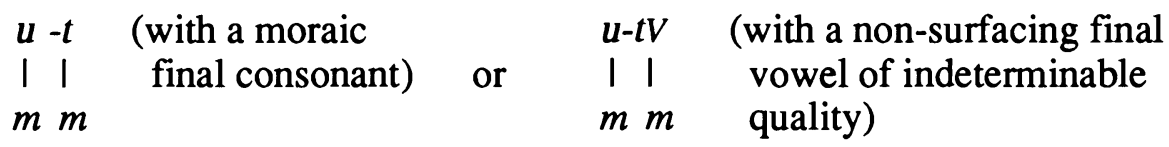

With two moras present, clearly one or the other can be the bearer of the underlying tone and the remaining mora the recipient of a contrasting default-inserted tone, making an eventual $\mathrm{H}-\mathrm{L}$ melody possible.

It is beyond the scope of the present discussion to compare the merits of the "moraic consonant" and "non-surfacing final vowel" approaches. Furthermore, this choice does not appear ultimately to affect in any critical way the eventual argument and conclusion concerning underlying low tones. Adopting, then, what is

10 Though another conceivable source for a second tone would be a contrasting floating tone, added by rule, this is not a viable hypothesis, since a general tone-adding rule would incorrectly cause the appearance of contour tones on a great many other words in the language. 
undoubtedly the least controversial path, I will assume for the purposes of this investigation that words in Ruwund end in vowels at the underlying level, but that short final vowels are devoiced and then (with the exception of $u$ ) deleted at some point by phonological rules. The rules accomplishing all this can, for present purposes, be lumped together and called simply the End Vowel Rules (EVR). As a word such as ut must still have two moras at the time of default tone insertion (so that a contrasting tone is inserted and a two-tone melody created), the End Vowel Rules are necessarily viewed as applying only after default tone insertion.

Strong clues as to the nature of the tonal components of the End Vowel Rules are provided by the Ruwund surface forms above in (2). The falling tones of $u t$ 'bow' and nsûc 'hair' lead to the conclusion that when a low-toned final vowel which follows a inigh-toned syllable is devoiced/deleted, its low tone reassociates back to the previous syllable.

\begin{tabular}{|c|c|c|}
\hline \multirow{4}{*}{$\begin{array}{l}\text { pre-EVR: } \\
\text { (post-default) }\end{array}$} & $\mathrm{H} \mathrm{L}$ & $\mathrm{H} \mathrm{H} \mathrm{L}$ \\
\hline & 11 & 111 \\
\hline & $u-t V$ & \\
\hline & $\stackrel{\mathrm{HL}}{L}$ & $\underset{I V L}{\mathrm{H} L}$ \\
\hline post-EVR: & $u-t$ & n-suc \\
\hline
\end{tabular}

If the above represent the correct post-default, pre-EVR representations for $\hat{u} t$ and nsûc, it follows that the representations for muj 'root' and nzal 'hunger' have final vowels linked to high tones just prior to the application of EVR, since it is a different tonal specification on the final vowel which must be causing these to surface with different tone, and since, if the final vowel is not L-linked, it must be H-linked.

\section{(5) mú-jv́ and ń-zálv́ as opposed to ú-tV̀ and ń-súc̀̀}

It can also be concluded that if a final vowel is linked to an $\mathrm{H}$ and the preceding syllable linked to a different $\mathrm{H}$ (as in the possible structures (6a) and (6c) below), the $\mathrm{H}$ of the final vowel simply disappears during EVR. There are two reasons for drawing this conclusion: first, there is no counter evidence in the language to indicate that floating $\mathrm{H}$ tones are left trailing after certain nouns, and second, representations in which a floating $\mathrm{H}$ is retained on the tonal tier after another $\mathrm{H}$ would be suspect in most contemporary autosegmental frameworks. ${ }^{12}$ (If, of

11 All word-initial nasal prefixes are syllabic and tone-bearing in Ruwund.

12 Even frameworks which readily permit representations with adjacent same-value tones on the tonal tier (i.e., those which don't accept the restriction on such imposed by the Obligatory 
course, it turns out that the final vowel is linked to the same $\mathrm{H}$ as the preceding syllable [as in (6b), (6d) and (6e) below], nothing at all need be said, since the branch would be assumed to disappear with the vowel.)

(a)

$\begin{array}{ccc}\mathrm{H} & \mathrm{H} \\ \mathrm{I} & \mathrm{I}\end{array}$

pre-EVR: $m u-j V$ or $m u-j V$ (post-default) (b)

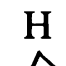

$\wedge$

mus (a) and (b)

post-EVR:

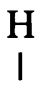

$m u-j$ (c)

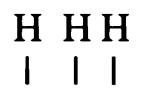

n-zalv (d)

(e)

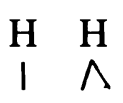

or $n-z a l v$

or n-zalv 13

Though nothing has yet been determined concerning which tone, $\mathrm{H}$ or $\mathrm{L}$, is underlying and which is default-inserted (EVR, coming as it does, after default tone insertion), the pre-EVR tonal specifications of four of the five Ruwund nouns in (2) have now been deduced (as shown in (5) above). Unsurprisingly, considering the close similarity of these nouns in Ciluba and Ruwund, they match Ciluba surface forms muji 'root', butà 'bow', nzala 'hunger', and nsukì 'hair' from the tonal standpoint. The case which is difficult to decide is that of mukil 'tail'. The easiest course would be to assume that the tone of the devoiced/deleted final vowel is L, like the syllable before it. An L after an L would be expected to disappear, just as an $\mathrm{H}$ after an $\mathrm{H}$, as a natural consequence of the autosegmental model. There is, however, good evidence that in Ruwund the $\mathrm{H}$ of a high-toned final vowel would also be dropped after L. No polysyllabic words in the language end in rising tones (which, if found, would suggest reassociation backward of a final stranded floating $\mathrm{H}$ ), despite the fact that one would expect that in at least some words a high-toned final vowel would follow a low tone. Furthermore, there exist some verb forms in the language which strongly indicate that floating $\mathrm{H}$ after $\mathrm{L}$ is

Contour Principle) would probably not want to support representations that maintain adjacent floating same-value tones.

13 The representation in $(6 \mathrm{c})$ is unacceptable in standard current autosegmental theory in that it violates the Obligatory Contour Principle, which disallows separate adjacent same-value tones within a single morpheme in underlying representations, if $\mathrm{H}$ is, in fact, the underlying tone. It is listed as one possibility here, however, both since there has been no determination as yet that $\mathrm{H}$ is an underlying tone and since the validity of the Obligatory Contour Principle is still contested by some theorists. 
deleted. 14 Note also that the Ciluba cognate mukila (like a number of other Ciluba cognates of this tone pattern) has a final high tone.

With these considerations in mind, and so as not to limit unnecessarily the possibilities for nominal tone before the various approaches can be examined, I will assume that the End Vowel Rules provide for the loss of an $\mathrm{H}$ associated to a final vowel regardless of the tone of the preceding syllable, and leave it that the preEVR tone of the last syllable of mukil is unknowably either high (v́) or low (V̀) (since either an $\mathrm{H}$ or an $\mathrm{L}$ after low-toned -kìl would be lost during EVR as EVRs have just been construed).

The following summarizes what has been either determined or assumed in these preliminaries to the discussion of Ruwund nouns:

- Ruwund words end underlyingly in vowels which, as a result of the End Vowel Rules, do not surface (with the exception of $u$, which surfaces in devoiced, non-tone-bearing form).

- The End Vowel Rules provide that when a word-final vowel is devoiced,

- the tone of that vowel is deleted in cases where it is of the same type as the tone linked to the previous syllable ( $\mathrm{H}$ after $\mathrm{H}, \mathrm{L}$ after $\mathrm{L})^{15}$ or when it is $\mathrm{H}$ following an $\mathrm{L}$;

- the tone of that vowel associates back to the previous syllable if it is an $\mathrm{L}$ following an $\mathrm{H}$.

These decisions have led to the hypothesis that surface tonal specifications, such as those in (7), are derived from pre-EVR tonal specifications, such as those in (8).

$$
\begin{array}{ll}
m u ́-j & \hat{u}-t \\
m u ́-j v & u ́-t v
\end{array}
$$

ń-zál

ń-zálV́ mú-kìl

mú-kìlV́lV̀ ń-sûc

ń-súc

14 The best evidence comes from Present Continuous tense forms, in which the final vowel (which in verbs would appear to be a) can be deduced to be high-toned, since the verb-stem final syllable (usually tense-marking suffix -in or -iin) is in most forms simply high-toned (i.e., no falling tone, which would indicate a pre-EVR low on the final vowel, ever appears there).

The form noshòdin 'I am burning a lot', since it is not *noshòdin must come from pre-EVR nóshòdíná (with a high-toned final vowel a), and the form nimutèkidiin 'I am placing for him,' since it is not *nimutèkìdîin, must similarly come from pre-EVR nímutèkìdíiná. In some short Present Continuous tense forms, however, the syllable preceding the final vowel is low-toned, meaning that a floating $\mathrm{H}$ (from final vowel a) follows a low after EVR has applied. Since no rising tone is produced, which, if present, would indicate that the floating $\mathrm{H}$ associates back to the preceding low-toned syllable, it would seem that the floating $\mathrm{H}$ is simply deleted.

noshìn 'I am burning,' coming from pre-EVR nóshìná is not *noshin

ninìn 'I am drinking,' coming from pre-EVR nínìná is not ninîin

15 It will be left as understood that a special rule deleting floating same-value tones $(\mathrm{H}$ after $\mathrm{H}$, $\mathrm{L}$ after $\mathrm{L}$ ) is unnecessary in many autosegmental frameworks, and that in most frameworks nothing at all needs to be stipulated if the devoiced final vowel was associated to the same tone as the preceding syllable in a branching representation (the branch simply disappearing when the vowel is devoiced). 
Note that no autosegmental structure is proposed as yet for the pre-EVR and postEVR versions of these nouns as they are represented in (7) and (8). Structure, the nature of the associations of tone-bearing units to tones on the tonal tier, is in some cases dependent upon what analysis of Ruwund tone is ultimately chosen. The preEVR representation of "hunger", for example, might conceivably be one of the representations in (9) depending upon what is ultimately taken to be the underlying form of this noun and what rules apply to the form prior to this stage. 16

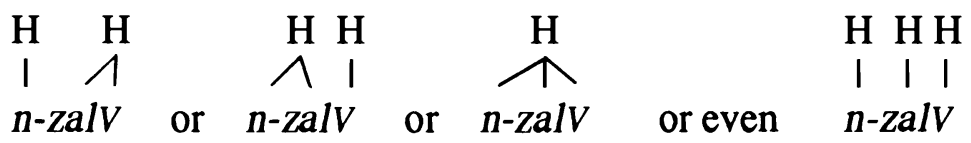

So that various different approaches (with some slightly different structural results) can be considered, the question of what structure generates the tonal specifications of (7) and (8) has intentionally been left open.

1.2 Possible analyses. As the five Ruwund nouns already cited represent the basic tone patterns of the language, 17 the pre-EVR tonal specifications of these nouns in (8) can be taken as the "goals" of any analysis. The tonal effects of EVR having already been described, the effort can now turn to deriving the pre-EVR stage under various hypotheses regarding the nature and distribution of underlying tones.

Since the view of Ruwund tone ultimately proposed in this paper-where $\mathrm{L}$ is underlying and $\mathrm{H}$ the default value - is unorthodox both in that it differs from the usual approach to Bantu languages and that it requires lifting Pulleyblank's proposed theoretical restriction that $\mathrm{L}$ be the default value, it is important to show that more conventional $\mathrm{H}$-based analyses are inadequate. The underlying lows analysis (in (1.2.2) below) will thus be considered in conjunction with two analyses which attempt to deal with the Ruwund data employing underlying H's and a default-L tone rule:

(i) a "non-shifting underlying $\mathrm{H}$ " analysis in which surface forms are viewed as directly reflecting underlying tone ( $\$ 1.2 .1$ below).

16 Again, some of these representations would be unacceptable to standard theory if $\mathrm{H}$ is an underlying tone, since separate, adjacent, same-value underlying tones within a morpheme would violate the Obligatory Contour Principle. $\mathrm{H}$ has not, however, yet been determined to be the underlying tone.

17 The overwhelming majority of Ruwund nouns are one or two syllables in length, with these five tone patterns representing the full range of tonal possibilities. The language does have some three-syllable and four-syllable nouns (with bisyllabic and trisyllabic roots), but a study of these does not contribute a great deal to the present discussion, since 1) these are generally not nouns for which Ciluba cognates or Proto-Bantu reconstructions can be found, and 2) tonal variation is here extremely common (e.g., uswèràl, uswèrâl or uswèral for 'laziness'). The tonal patterns are, nevertheless, provided at the end of the paper. 
(ii) a "shifting underlying $\mathrm{H}$ " analysis in which surface forms are seen as manifesting a shift of an underlying $\mathrm{H}$ one mora to the left ( $\$ 1.2 .3$ below).

As no previous autosegmental analyses of Ruwund tone have ever been proposed, these $\mathrm{H}$-based alternative analyses are also new. They are not, however, mere straw-man constructs, conceived with built-in defects to insure their ultimate failure, but rather true attempts to pursue the most promising alternative $\mathrm{H}$-based hypotheses as far as they go.

1.2.1 The non-shifting underlying $H$ analysis. In this hypothesis, noun prefixes are all underlyingly high-toned, and root syllables are underlyingly high or toneless. Low tones are inserted by a default rule.

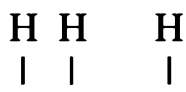

Underlying: $\quad m u-j V \quad u-t V$

Default-L:

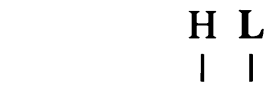

$u-t V$

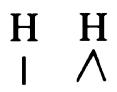

n-zalv

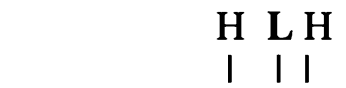

$\begin{array}{cc}\mathrm{H} & \mathrm{H} \\ \mathrm{I} & \mathrm{I}\end{array}$
$\mathrm{H}$

mu-kilv or mu-kilv

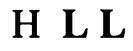

mu-kilv or mu-kilv

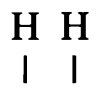

n-suc $V$

The resulting representations clearly do account for the "goal" tonal specifications of (8), repeated below.

$m u ́-j \bar{~} \quad u ́-t \grave{V}$

ń-zálv́

mú-kìlv́ or mú-kìlv̀

$\ddot{n}$-súc

After EVRs apply, representations are as follows.

(11)

post-EVR:

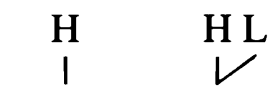

$m u-j$

$m u j$, $u-t$

ût

'bow'

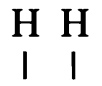

n-zal

nzal

'hunger'

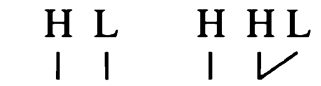

mu-kil n-suc

Note that while this approach maintains a similarity with Proto-Bantu in that it employs underlying H's and default L's, it also views Ruwund as being radically different: Ruwund words are here seen as bearing underlying tone in exactly the opposite locations that Proto-Bantu did (resulting in a situation, visible in (10) above, in which moras tonally specified at the underlying level now far outnumber those remaining unspecified). If, for example, Proto-Bantu had a straightforward tonal system, underlying representations for these words in that language would presumably have been as in (12) (with $p x$ standing for nominal prefix), to which the low default rule applied, producing the forms in (13). 
(12)

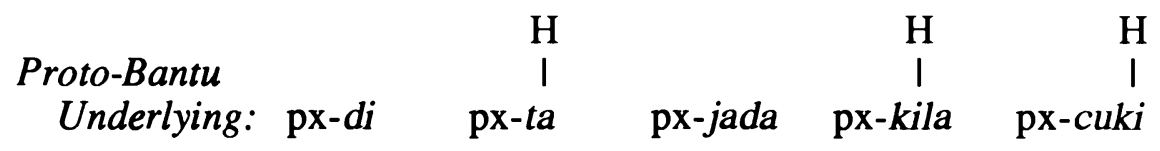

(13)

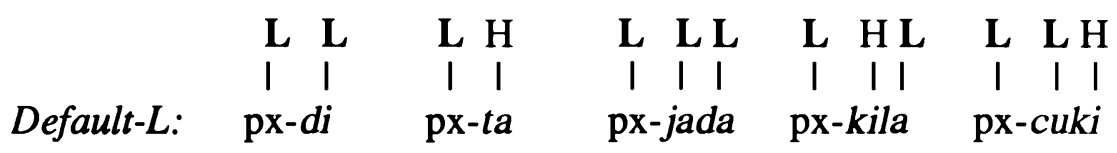

1.2.2 The underlying $L$ analysis. In this view, noun prefixes are all underlyingly toneless, and root syllables underlyingly low or toneless. High tones are inserted by a default rule.

Underlying: mu-jV u-tV n-zalV mu-kilv or mu-kilv n-sucV

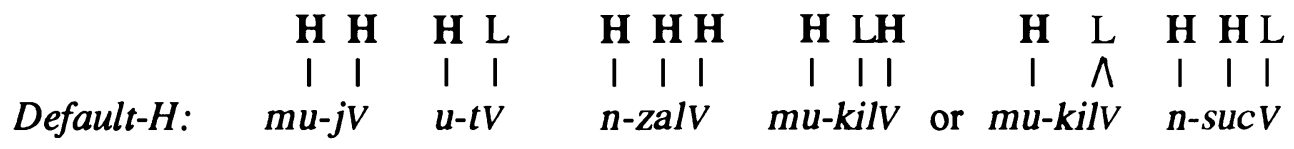

These representations also account satisfactorily for the "goal" tonal specifications of (8), repeated below. 18

18 A note on rule ordering: while it is perhaps tempting to view the Default $\mathrm{H}$ assignment as following the End Vowel Rules, thus eliminating the necessity for the components of EVR which delete floating high tones, this would mean that at one point in the derivations of ût and nsûc (after the deletion of the final vowel but before $\mathrm{H}$ default) a representation would have to be preserved in which words end in a floating $L$ though there exist toneless segments to which $L$ might link. This is probably unacceptable from a theoretical standpoint. 


$$
m u ́-j V ́ \text { ú-tV̀ ń-zálv mú-kìlv́ or mú-kìlv̀ ń-súcv̀ }
$$

This analysis is more economical than the first in that many fewer underlying segments are tonally specified at the underlying level, most moras only receiving tonal specification via the default rule. Though the value of the underlying tone is changed, Ruwund appears in this view much more similar to Proto-Bantu from a structural standpoint, noun prefixes remaining underlyingly toneless and underlying tonal associations for noun roots being for the most part as in (12) above.

1.2.3 The shifting underlying $H$ analysis. By supposing that Ruwund employs underlying high tones, but that these highs are realized in surface forms one mora to the left of their original locations, the third analysis permits a conventional $\mathrm{H}-$ based, L-default approach to be combined with an underlying tone distribution which is a very close match to the Proto-Bantu one in (12) above.

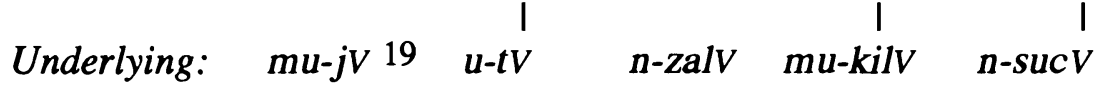

The realization of the underlying $H$ tones one mora to the left in surface forms would presumably, in an autosegmental analysis, be the result of a two-component

\begin{tabular}{|c|c|c|c|c|c|}
\hline \multirow[t]{2}{*}{ Underlying: } & $m u-j V$ & $\begin{array}{r}\mathrm{L} \\
\mathrm{I} \\
u-t V\end{array}$ & $n-z a I V$ & $\stackrel{\mathrm{L}}{\mathrm{I}}$ & $\begin{array}{r}\mathrm{L} \\
\mathrm{I} \\
n-s u c V\end{array}$ \\
\hline & \multicolumn{3}{|c|}{$\mathrm{L}$} & L & $\mathrm{L}$ \\
\hline \multirow[b]{3}{*}{ ?Default-H: } & $m u-j$ & $u-t$ & $n$-zal & mu-kil & $n$-suc \\
\hline & $\underset{\mathrm{I}}{\mathrm{H}}$ & $\underset{L}{\mathrm{H}} \mathrm{L}$ & $\mathrm{H} \mathrm{H}_{\mathrm{H}}^{\mathrm{H}}$ & $\begin{array}{ll}\mathrm{H} & \mathrm{L} \\
\mathrm{L} & \mathrm{L}\end{array}$ & $\underset{\mathrm{H}}{\mathrm{H}} \mathrm{L}$ \\
\hline & $m u-j$ & $u-t$ & $n-z a l$ & mu-kil & $n$-suc \\
\hline & & \multicolumn{2}{|l|}{$\stackrel{\mathrm{HL}}{V}$} & & $\underset{I}{\mathrm{H}} \underset{V}{\mathrm{HL}}$ \\
\hline \multirow[t]{2}{*}{ Floating L Linkage: } & & \multicolumn{2}{|l|}{$u-t$} & & $n$-suc \\
\hline & $m u j$ & $\hat{u} t$ & nzal & mukìl & nsûc \\
\hline
\end{tabular}
shift rule, the first part of which (16, Shift A) spreads a tone leftward to the adja-

19 Note that the roots $-j V$ 'root' and -zaIV 'hunger', though high in the "goal" representations of (8), must remain underlyingly toneless under this analysis in order to be tonally differentiated from the other roots. 
cent mora, and the second part of which (16, Shift B) deletes the rightmost branch of a branching tone.

(16)

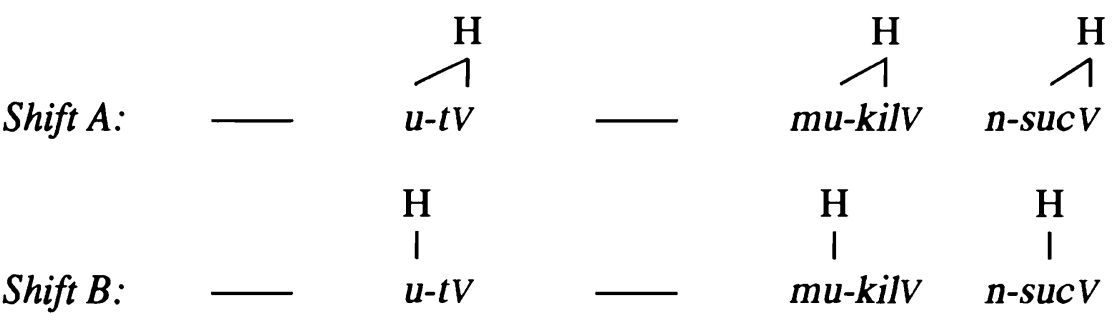

Clearly, additional rules are required under this view if the pre-EVR "goal" specifications of (8) are to be generated. To account for the high tones of mú-jv and ń-zálV́, which have no underlying $\mathrm{H}$ 's, an $\mathrm{H}$ must first be added to the string via some type of general high insertion rule, then spread, again via a general rule, to several syllables. (If no $\mathrm{H}$ is inserted, all syllables in these words would be expected to receive an $\mathrm{L}$ specification via the eventual application of the low default rule.)

Leaving aside, for the moment, the question of exactly where the additional $\mathrm{H}$ is inserted, it is clear that the mora immediately to the right of any shifted lexical $\mathrm{H}$, i.e., the mora which was the original location of the lexical $\mathrm{H}$, must be protected from receiving an $\mathrm{H}$ specification under the new proposed general spread rule, since in the goal specifications of (8) this mora is low-toned. (The low will be introduced by the default-L assignment rule which, of course, necessarily applies after the rule spreading $\mathrm{H}$ generally. And to be eligible for it, the mora to the right of an $\mathrm{H}$ must be toneless at the time the $\mathrm{L}$ default rule applies.) The only obvious way in which this mora can be protected from the general $\mathrm{H}$ spread rule is to have the rule operate from right to left and stop before it gets to the mora which follows a shifted lexical $\mathrm{H}$. (If, on the contrary, H's were spread left-to-right during the general spread rule, the mora to the right of a shifted lexical $\mathrm{H}$ would be reassociated to this $\mathrm{H}$, both undoing the work of "Shift B" and ensuring that this mora become ineligible for a low tone under the default $\mathrm{L}$ rule later.)

Turning now to the question of the rule inserting H's, if "general spread" is to be right-to-left, and if all of the moras of an underlyingly toneless word such as nzalV 'hunger' are to benefit, the new $\mathrm{H}$ is necessarily inserted at the right edge of the word (or potentially, at the right edge of the phrase) and linked to the last vowel. For the purposes of this discussion, I will assume that both the $\mathrm{H}$ insertion rule and the general $\mathrm{H}$ spread rule operate at the phrasal level and call them "Phrasal H Add" and "Phrasal H Spread", respectively, though this assumption is in no way critical. Phrasal $\mathrm{H}$ Add will be viewed as supplying an $\mathrm{H}$ to the last mora of any phrase as long as that mora is toneless and not preceded by an $\mathrm{H}$-linked mora. Phrasal $\mathrm{H}$ Spread will be viewed as an iterative rule spreading all $\mathrm{H}$ 's leftward (even across word boundaries) to all toneless moras except those preceded 
by $\mathrm{H}$-linked moras. Preventing both Phrasal H Add and Phrasal H Spread from linking H's to moras that are themselves preceded by $\mathrm{H}$-linked moras allows moras which follow $\mathrm{H}$-linked ones to remain toneless and to thus be eligible for low tones via the $\mathrm{L}$ default rule. The restriction is far from an unnatural one. It could easily be motivated by the Obligatory Contour Principle. 20

With Phrasal H Add and Phrasal H Spread in place, the derivations of (16) can be continued as below. (Note: So that all of the sample nouns receive tonal specification in these derivations, all are here considered to be phrase-final.)

20 It might, at first perusal, appear that a simple reordering which puts Phrasal $\mathrm{H}$ Add and Phrasal H Spread before the second part of the shift rule (Shift B, which delinks rightmost branches) would eliminate the need for the restrictions on the rules themselves. If, for example, the $\mathrm{H}$ of mukilv is allowed to remain linked to both its original mora (i) and the mora to which it has spread in Shift A (ú), then an $\mathrm{H}$ can be inserted on the last mora without restriction. When Shift $B$ applies, mora $i$ will lose its association and be ready to receive an $L$ association by default.

\begin{tabular}{|c|c|c|c|c|c|c|}
\hline $\begin{array}{c}\mathrm{H} \\
\text { I } \\
\mathrm{mu}-k i V \\
U R \rightarrow\end{array}$ & $\overbrace{\substack{\text { mu-kiV } \\
\text { Shift A }}}^{\mathrm{H}}$ & $\begin{array}{c}\bigwedge_{\text {mu-kiIV }}^{\mathrm{H}} \mathbf{H} \\
\text { Phr.H-Add }\end{array}$ & $\begin{array}{l}\text { (NA) } \\
\text { Phr.H-Sprd. }\end{array}$ & $\begin{array}{l}\mathrm{H} \quad \mathrm{I} \\
\text { I } \\
\text { Shift } \\
\text { ShiV } \\
\text { B }\end{array}$ & $\begin{array}{c}\mathrm{H} \mathbf{L ~ H} \\
\text { I I I } \\
\text { Du-kiN. Low }\end{array}$ & $\begin{array}{l}{ }_{1}^{\mathrm{H}} \mathrm{L} \\
\text { I । } \\
E V R\end{array}$ \\
\hline
\end{tabular}

This approach, however, runs into problems with such short, contrasting forms as muj 'root' and $\hat{u}$ ' 'bow', since when an $\mathrm{H}$ is added to muj and spread by Phrasal H Spread, a representation is created which is identical to that of $\hat{u} t$ after Shift A.

\begin{tabular}{|c|c|c|c|c|c|c|}
\hline $\begin{array}{l}m u-\dot{j v} \\
U R \rightarrow\end{array}$ & $\begin{array}{l}\text { (NA) } \\
\text { Shift A }\end{array}$ & $\begin{array}{c}\mathrm{H} \\
\mathrm{I} \\
\text { mu-jV } \\
\text { Phr.H-Add }\end{array}$ & $\begin{array}{l}\text { Hu-jV } \\
\text { Phr.H-Sprd. }\end{array}$ & $\begin{array}{c}\mathrm{H} \\
\mathrm{I} \\
\text { mu-jV } \\
\text { Shift B }\end{array}$ & $\begin{array}{c}\text { H L } \\
\text { I I } \\
m u-j V \\
\text { Def. Low }\end{array}$ & $\underset{\substack{\mathrm{HL}-j \\
E V R}}{\mathrm{H}}$ \\
\hline $\begin{array}{r}\mathrm{H} \\
\mathrm{l} \\
u-t \\
U \\
U R \rightarrow\end{array}$ & $\begin{array}{c}\mathrm{H} \\
\text { Shift } \mathrm{A}\end{array}$ & $\begin{array}{l}\text { (NA) } \\
\text { Phr.H-Add }\end{array}$ & $\begin{array}{l}\text { (NA) } \\
\text { Phr.H.-Sprd. }\end{array}$ & $\begin{array}{l}\mathrm{H} \\
\text { I } \\
\text { u-t } V \\
\text { Shift } B\end{array}$ & $\begin{array}{l}\text { H L } \\
\text { I I I } \\
\text { u-t } V \\
\text { Def. Low }\end{array}$ & $\begin{array}{c}\mathrm{HL} \\
\mathrm{mu-t} \\
E V R\end{array}$ \\
\hline
\end{tabular}



Default Low:
$\mathrm{H}$
(from (16)): $\quad m u-j v$
$u-t V$
$\mathbf{H}$
$\mathbf{I}$
Phrasal H Add: $\quad$ mu-jV
Phrasal H Spread: $\quad$ mu-jV

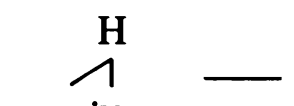
(blocked)
n-zalv

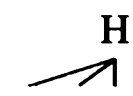
n-zalv
(blocked)

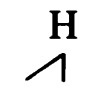
n-sucV

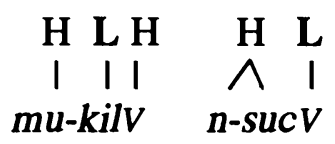

Representations which account for the "goal" specifications of (8) above, repeated below, have now been derived.

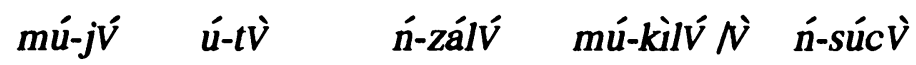

Several things should be noted about this analysis. First, "reversal" is here a synchronic phenomenon, the still-active shift rules resulting in surface forms with the appearance of historic reversal. Secondly, though a close similarity to ProtoBantu is maintained at the underlying level, the commonality comes only at considerable cost, the inclusion of Shift A, Shift B, Phrasal High Add, and Phrasal High Spread making this approach already significantly less elegant than either of the others. Finally, there is the problem that though the derivations are successful from a purely mechanical standpoint, the approach seems to violate the spirit of underspecification theory. A default rule normally applies to "elsewhere" environments, i.e., to any moras not linked to underlying tones or affected by deep-level tonal processes. By this definition, the real default rule in this analysis is thus the combination of Phrasal H Add and Phrasal H Spread (which supply tones to underlyingly toneless nouns such as nzal 'hunger'). In contrast, moras which receive "default" lows under this approach actually represent consistent, highly definable locations: exactly (and only) those moras which bear lexical tone.

\section{Verbal Tone}

Though an examination of nouns is useful in suggesting the main possible approaches to Ruwund tone, and, thus, for providing a foundation from which to look at other tonal phenomena in the language, it cannot resolve the question of 
which type of analysis is ultimately the most satisfactory, nor can it fully reveal the tone system of Ruwund. For additional insight one must look at verb forms, where there exists the opportunity to observe different combinations of a restricted set of morphemes. In sections 2.1, 2.2 and 2.3 below, forms of the verb -futol 'pay (for) a lot' (made up of the root -fut 'pay' and the intensive extension -ol/od) are examined in three tenses - the Recent Past, the Near Past, and the Present Continuous. (As verbs do not bear lexical tone in Ruwund, patterns are the same for all other bisyllabic, consonant-initial stems. Forms for longer and shorter stems (some data for which are provided at the end of the paper) follow the patterns for bisyllabic stems except where noted.)

2.1 The shifting underlying $H$ analysis-second look. The "shifting underlying $\mathrm{H}$ " analysis is the one which most quickly runs into serious difficulties when verbs are considered. One generalization that emerges immediately from the analysis as it was developed in section 1.2.3 above, is that in this system, words which contain no low tones at the surface level contain no H's at the underlying level (since it is the site of an underlying $\mathrm{H}$ that eventually surfaces as low). 21 Thus, since the first person Recent Past tense form namamufutodin 'I paid him a lot for them' contains no surface lows, it can be concluded that all of the morphemes which make up this form-object prefixes ma- 'them' and mu- 'him', verb root -fut, verbal extension $-o l$, tense-marking suffix -in, non-surfacing final vowel -a, first person singular subject prefix ni- and tense-marking prefix a- (ni- and a- together forming an initial syllable na- having a short vowel)-are toneless in this tense at the underlying level. The form's surface high tones must all result from "Phrasal H Insertion" and "Phrasal H Spread".

21 It is unlikely that a lack of low tones on the surface could instead be explained as the result of an interaction of underlying H's that results in all underlying H's being deleted by rules. 
(18)

$$
\text { Underlying: ni-a-ma-mu-fut-ol-in-a }
$$

Shift A \& B:

Phrasal H Insertion: $\quad$ ni-a-ma-mu-fut-ol-in-a

Phrasal H Spread $(\leftarrow): \quad$ ni-a-ma-mu-fut-ol-in-a

Default Low:

EVR:

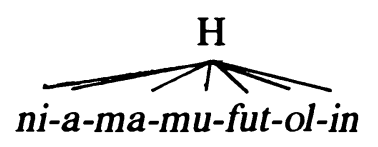

namafutodin

'I paid him a lot for them'

The corresponding third person form, wàmàmùfutodin 'she paid him a lot for them', has surface lows on all prefixes. Since the only morpheme which distinguishes this form from the first person one is the third person singular subject prefix (w)u- /wu-/ (which, replacing the first person prefix ni-, combines with tense-marking prefix a- to form an initial syllable wa- having a short vowel), 22 this must be the cause of the low tones appearing in the surface form. To be the cause of the low tones, however, wu- must be underlyingly high-toned in this system, since contrasting ni- was necessarily toneless, and "toneless" or "high" are the only possible underlying specifications. "Shift" would be expected to cause $w u-$ to lose its high and, thus, become eligible for a low specification via the default rule. (That wu- would be high-toned underlyingly is, of course, not at all surprising, since third person subject prefixes are high-toned in many Bantu languages.)

22 For reasons that are too lengthy to be explained here, the third person singular subject prefix in Ruwund is best considered to have acquired an initial $/ w /$ at the underlying level, though this consonant is not always articulated and is not used in spellings when /wu/ is word-initial (e.g., the Present Continuous tense form ùfütòdin (wu-fut-ol-in-a) 's/he is paying a lot'). 


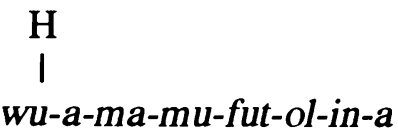

A first problem for this analysis is how, exactly, to construe things so that a default low tone eventually appears on subject prefix wu-. The underlying high of this prefix has nowhere to go during Shift, since the prefix is at the beginning of the word (and, potentially, at the beginning of the phrase). Shift A (one-mora leftward spread) cannot apply at all. Shift B (right-branch delinking) could be prevented from applying to $w u$ - by a stipulation that the rule applies only to branching tones, but then it becomes unclear how this syllable will eventually become toneless and, thus, the recipient of a low default tone. ${ }^{23}$ If, on the other hand, Shift B is viewed as causing the $\mathrm{H}$ of wu- to delink and become a floating tone, it is not obvious how "Phrasal H Spread" would be prevented from eventually assigning $\mathrm{H}$ to this syllable (thereby eliminating the toneless gap that one would want to become low-toned during default tone assignment). It is true that $\mathrm{H}$-Spread cannot spread a high tone to a position immediately adjacent to another high. But the $\mathrm{H}$ brought by subject prefix wu-, if it has been floated by Shift B, no longer really has a position that a tone rule could identify.

Since it may prove theoretically acceptable to claim that the shifted floating $\mathrm{H}$ of subject prefix wu- has been moved to a position "just prior to the word" (thus enabling it to inhibit $\mathrm{H}$ Spread to the word's first syllable), this problem may be merely awkward rather than catastrophic. Assuming then, that the question of how initial syllable wa- eventually comes to be assigned a low default tone can be resolved, there remains the greater problem of explaining how object prefixes -maand -mu- also come to be low-toned on the surface, since neither is low in the first person form. The only possible cause of these low tones is the same one as for the low of wa, the underlying $\mathrm{H}$ of subject prefix wu- (which shifts off wu- and protects it from $\mathrm{H}-$ Spread), the first person form having made it clear that all other morphemes are underlyingly toneless. There doesn't seem to be any way, however, that the shifted $\mathrm{H}$ of $w u$ - could also protect ma- and $m u$ - from $\mathrm{H}-$ Spread, since they are not adjacent to it (see 20).

23 The idea that wu-retains its $\mathrm{H}$, with a- becoming the recipient of the default low, and that the falling tone which results is subsequently simplified to just $\mathrm{L}$ might seem to be a possible solution in this particular form, but turns out to be unworkable in other tenses. (Consider, for example, Present Continuous tense form ùmàmùfùtòdin 'she is paying him a lot for them,' which lacks an a- tense-marking prefix to serve as a recipient of the default low but which still has a low-toned initial syllable.) 
after Shift A \& B:

Phrasal H Insertion:

Phrasal H Spread $(\leftarrow)$ :

Default Low: (after EVR:) correct form:

$$
\text { wu-a-ma-mu-fut-ol-in-a }
$$

$\mathrm{H}$

$\mathrm{H}$

wu-a-ma-mu-fut-ol-in-a

$\mathrm{H}$

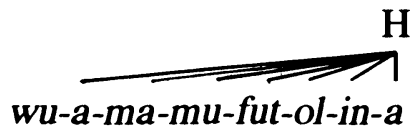

$\mathrm{H}$

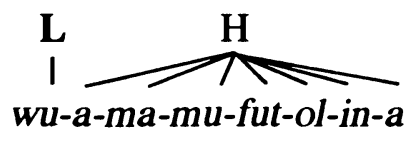

*wàmamufutodin

wàmàmùfutodin

'she paid him a lot for them'

Though it might at first seem desirable to view the $\mathrm{L}$ which is eventually assigned to the subject prefix $w u$ - by the default rule as subsequently spreading to the object prefixes, there is no straightforward way in which lows could spread in this analysis. Lows are introduced by default at the ends of derivations, by which time the Phrasal H Spread rule has spread a high to most of the prefixes (including object prefixes ma- and mu-). Ordering Default-L before Phrasal $\mathrm{H}$ Spread is, of course, of no help. If the default rule assigned L's to tonally unspecified moras prior to Phrasal H Spread, the latter would never apply, since all the syllables to which it has been viewed as spreading in the derivations above would already have been linked to L's. Long incorrect strings of low tones would be the result, as in *nàmàmùfùtòdin and *wàmàmùfùtòdin. $\mathrm{A}$ post-default rule spreading $\mathrm{L}$ to an adjacent $\mathrm{H}$-toned syllable to the right, along with a falling-tone simplification rule, could conceivably get initial object prefix ma- to surface low-toned, but since two-step rule sequences cannot normally be iterative in non-cyclic generative accounts, such an approach has little hope of explaining the surface low of second object prefix $m u$-, and would furthermore make forms with single-syllable lows (not manifesting any such spread)_-such as wàfutin 'she paid'-difficult to generate.

The problems for this analysis only worsen when Present Continuous tense forms are considered. In this tense, different in its morphological makeup from the Recent Past tense only in its non-use of tense-marking prefix -a, surface lows show up in the verb stem, indicating the presence of a grammatical $\mathrm{H}$ (docking, 
presumably, to the first verb syllable). Since prefixes have the same surface tone as in the Recent Past tense, a reasonable starting assumption is that, as in the Recent Past tense, first person subject prefixes are toneless at the underlying level while third person prefixes are $\mathrm{H}$-toned. But the rules, all of which appear to be necessary in some form, again produce the wrong results, this time for both first person and third person forms.

\begin{tabular}{|c|c|c|}
\hline & $\begin{array}{c}\mathrm{H} \\
\mathrm{I}\end{array}$ & $\begin{array}{cc}\mathbf{H} & \mathbf{H} \\
\mathbf{I} & \mathrm{I}\end{array}$ \\
\hline nderlying: & ni-ma-mu-fut-ol-in-a & wu-ma-mu-fut-ol-in-a \\
\hline ift A \& B: & 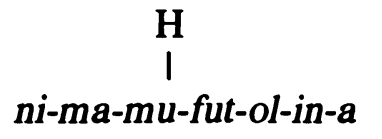 & $\begin{array}{ll}\text { H } & \text { H } \\
& \text { wu-ma-mu-fut-ol-in-a }\end{array}$ \\
\hline Insertion: & $\begin{array}{cc}\mathrm{H} \\
\mathrm{I}\end{array}$ & 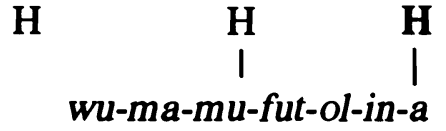 \\
\hline pread $(\leftarrow)$ : & $\overbrace{\text { ni-ma-mu-fut-ol-in-a }}^{\mathrm{H}}$ & $\overbrace{\text { wu-ma-mu-fut-ol-in-a }}^{\mathrm{H}}$ \\
\hline & $\overbrace{n i-m a-m u-f u t-o l-i n-a}^{H}$ & 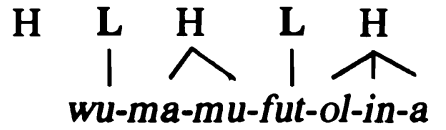 \\
\hline (after EVR): & *nimamufutodin & *ùmamufütodin \\
\hline : & $\begin{array}{l}\text { nimamufutodin } \\
\text { 'I am paying him a lot } \\
\text { for them' }\end{array}$ & $\begin{array}{l}\text { umamàufutodin } \\
\text { 'she is paying him a lot } \\
\text { for them' }\end{array}$ \\
\hline
\end{tabular}

The serious mechanical problems of the shifting underlying $\mathrm{H}$ approach are easily summarized. In this view, low tones are limited to the role of providing default tonal specification to single-mora gaps of tonelessness left by the Phrasal $\mathrm{H}-$ Spread rule (which is constrained so as not to spread an $\mathrm{H}$ to moras adjacent to any H-linked moras). But Ruwund verb forms contain many long strings of consecutive low-toned syllables in addition to strings of high-toned ones. Gaps of tonelessness are not easily enlarged to account for multi-syllable strings of lows on the surface, since tonelessness can not be spread by rules in the way that tones can. (Low tones could spread, but in this analysis they enter the picture too late to cover any long distances, most toneless moras at this point already having received an $\mathrm{H}$ 
specification as a result of Phrasal H Spread.) Particularly problematic is generating forms such as ùmàmùfùtòdin (21), where the toneless gaps following two different underlying H's must connect. In the derivation above, for instance, there would not seem to be any means available to explain the eventual disappearance (in the correct form) of the $\mathrm{H}$ (originally from - fut but shifted to $\mathrm{mu}-$ ) separating the first gap (located at $w u-$ ) from the second (located at -fut).

\subsection{The non-shifting underlying $H$ analysis-second look. As developed in} $\S 1.3 .1$ above for nouns, the non-shifting underlying $\mathrm{H}$ analysis had only one rule: default-L insertion. All surface high tones were derived directly from underlying high tones. This clearly will not suffice for verb forms, since there exist verbal morphemes which surface with high tones in some forms but with low tones in others. Object prefixes in the Recent Past tense, for instance, are high-toned in first person forms but low-toned in third person forms. However, addition of a rule to the system-operating only in verbs and spreading an $\mathrm{H}$ to all toneless syllables to the right within the domains of "prefix" and "verb stem"-permits this approach to handle easily basic forms in both the Recent Past and Present Continuous tenses.

In the Recent Past, the verb stem would be assumed to have a first syllable underlying $\mathrm{H}$ (i.e., a floating grammatical $\mathrm{H}$ which links to the first verb mora).

(22)

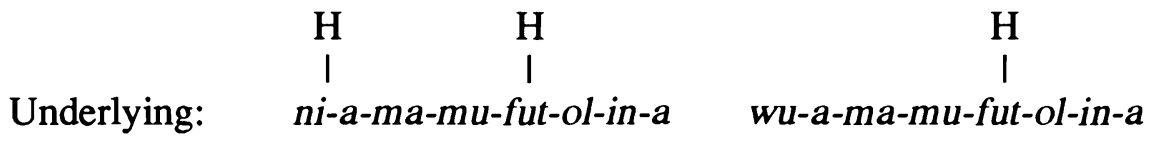

$\mathrm{H}$

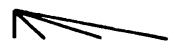

H Spread $(\rightarrow)$ : (in domain)

Default Low: (after EVR): namamufutodin

'I paid him a lot for them'
$\mathrm{H}$

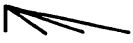

wu-a-ma-mu-fut-ol-in-a

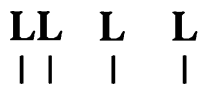

$N_{-1 n-a}^{H}$

wu-a-ma-mu-fut-ol-in-a

wàmàmùfutodin

'she paid him a lot for them'

In the Present Continuous tense, the verb stem itself is toneless, but tensemarking suffix -in is linked to an underlying $\mathrm{H}$. 
(23)

Underlying: ni-ma-mu-fut-ol-in-a

H Spread $(\rightarrow)$ : $\quad$ ni-ma-mu-fut-ol-in-a (in domain)

Default Low: ni-ma-mu-fut-ol-in-a (after EVR): nimamufùtòdin

'I am paying him a lot for them'

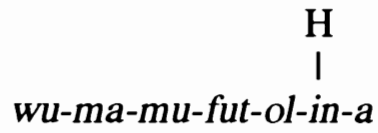

wu-ma-mu-fut-ol-in-a

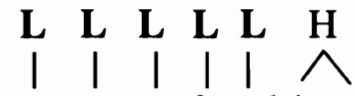

wu-ma-mu-fut-ol-in-a

ùmàmùfùtòdin

'she is paying him a lot for them'

It is in Near Past tense data, where suffix -in of the Recent Past tense is replaced by -ang, that the major shortcomings of the non-shifting underlying $\mathrm{H}$ analysis are revealed.24 While all prefixes are high-toned in the Recent Past form namamufutodin 'I paid [days or weeks ago] him a lot for them', object prefixes mà- and mù- are low-toned in Near Past form namàmùfutolang 'I paid [yesterday] him a lot for them'. For ma- and $m u$ - to remain open for default-L assignment in the Near Past form, in this tense something must block the spread of the underlying $\mathrm{H}$ of $n i-$, the first person subject prefix. It is not at all obvious, however, what that something could be.

As at the underlying level there is only a toneless/H contrast, and as tonelessness is the environment in which $\mathrm{H}$-Spread occurs, only another underlying $\mathrm{H}$ could be blocking $\mathrm{H}$-Spread from prefix $\mathrm{ni}$ - to $\mathrm{ma}$ - and $\mathrm{mu}$ - in namàmùfutolang. In other words, namàmùfutolang might be viewed as containing three underlying $\mathrm{H}$ 's rather than the two posited for the Recent Past form namamufutodin in (22). Clearly, an additional underlying $\mathrm{H}$ would have at least the potential to serve as a blocker of the rightward spread of the $\mathrm{H}$ on ni-, since the Obligatory Contour Principle (OCP) could be invoked (as in the "Shifting underlying H's" analysis) to cause spread to come to a stop one syllable or one mora away from another $\mathrm{H}$ tone. This would leave a toneless gap which would later be assigned an L by the default rule.

24 The Near Past pronunciations used in this study are those of elder speakers of the Musumban dialect (the version of the language spoken in the Ruwund capital city of Musumb), as well as of all-age speakers of the Kalamban dialect. The innovations in pronunciation now standard for younger Musumbans are still under investigation. 
With the correct limitations on the H-Spread Rule, a representation like (24a) might go to one like (24c) rather than to one like (24b), allowing an L to be inserted eventually by the default rule (as in (24d)).

(a)

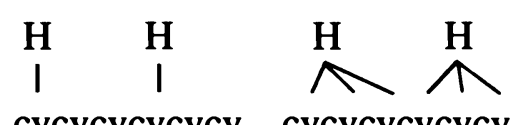

(c)

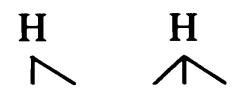

crevereverev (d)

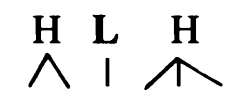

crevevevevev

Another way in which an additional $\mathrm{H}$ might cause a toneless gap is through a deletion rule, also OCP motivated, which removes the second of two adjacent H's. 25

With a rule in the grammar deleting $\mathrm{H}$ after $\mathrm{H}$, ordered after $\mathrm{H}-\mathrm{Spread}$, a representation like (25a) might go to one like (25b) during spread, but then become like (25c) (via deletion) and eventually like (25d) (via default).

(25) (a)

H H
I I
cvevev (b)

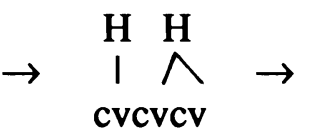

(c)

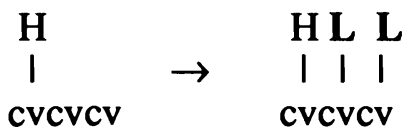

There are, however, a number of problems with these approaches for Ruwund. One that might already be obvious is that an $\mathrm{H}$ was allowed to spread to a position adjacent to another $\mathrm{H}$ in the analysis of Recent Past form namamufutodin (in (22)). This would seem to rule out both the "limitation of spread" and "adjacent tone deletion" ideas, but perhaps that form can be handled as a special case since the two H's belong to different domains. A more serious difficulty for the hypothesis that additional underlying H's are what cause low tones to appear in namàmùfutolang is that no positioning of them seems to work.

Looking first at the possibility that any additional underlying H's responsible for low mà- and mù- in namàmúfutolang are located in the prefix domain, it can quickly be concluded that the tense-marking prefix a-, minimally, would have to be viewed as bearing an underlying $\mathrm{H}$. This follows from the fact that a low tone also appears in nafùtolang 'I paid a lot', a Near Past form which employs no object prefixes at all-though now the low tone presumed to be caused by an additional prefixal $\mathrm{H}$ appears on the first stem syllable rather than on an object prefix. Since in this analysis the first person subject prefix ni- is viewed as high-toned and the third person subject prefix $w u$ - as toneless, underlying representations for

25 Often referred to as Meeussen's Rule, tone deletion of this type is found in a number of Bantu languages. 
nafùtolang and wàfùtolang 'she paid a lot' would presumably be as in (26a) below, contrasting with those of the Recent Past in (26b).

(a) Near Past

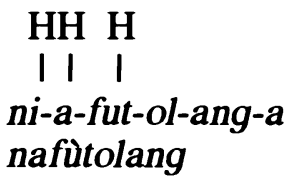

H H
I I
wu-a-fut-ol-ang-a
wàfùtolang (b) Recent Past

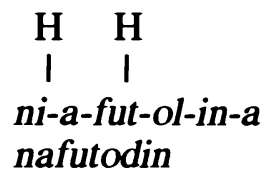

'I paid a lot'

Representations for forms with object prefixes would be as in (27a) or (27b), depending upon whether object prefixes are themselves viewed as underlyingly high or toneless.

(27)

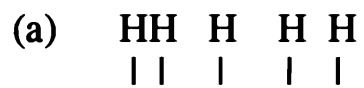

ni-a-ma-mu-fut-ol-ang-a or (b)

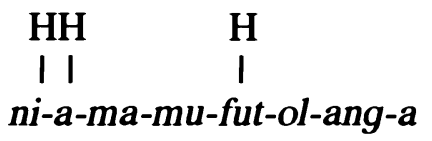

namàmùfutolang 'I paid him a lot for them'
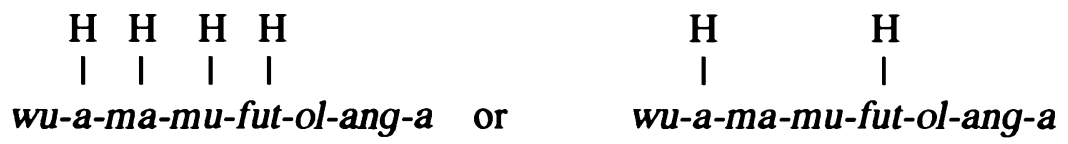

wàmàmùfutolang 'she paid him a lot for them'

It is clear that the underlying $\mathrm{H}$ of the first person subject prefix ni- might be viewed as causing deletion of the $\mathrm{H}$ assumed to belong to a- (and possibly $\mathrm{H}$ 's belonging to the object prefixes), thus creating a toneless gap right after the subject prefix that would receive a low tone by the default rule. In one way or another, the first person forms nafùtolang and namàmùfutolang could probably be generated from such a starting point (though the alternation in the syllable -fu- poses something of a challenge). Even without going into the details, however, it is already obvious that such an approach will have a very hard time generating the third person forms wàfùtolang and wàmàmùfutolang. These surface with no highs in the prefix area, yet, since the third person subject prefix $w u$ - is toneless, there are no tones around that could be causing the $\mathrm{H}$ of a- to undergo deletion. The $\mathrm{H}$ of 
a- would be expected to show up in some form in the prefix area of the surface forms (perhaps as a rising tone on the syllable containing a-, as in *wăfùtolang and *wămàmùfutolang, or as a falling tone on the following syllable, as in *wàfûtolang and * wàmâmùfutolang).

If an $\mathrm{H}$ on a- (and, possibly, on object prefixes) is not causing the difference between the Near Past surface form namàmùfutolang and the Recent Past form namamufutodin, another hypothesis would be that differences in stem tone are the source. It turns out, however, to be difficult to claim that Near Past forms lack altogether the tense-inserted grammatical $\mathrm{H}$ which makes Recent Past stem -futodin high-toned in both first and third person forms, since most Near Past stem syllables also surface high-toned. Only the first stem syllable is low-toned in Near Past forms, and then only when no object prefixes are present (e.g., -fù- in nafùtolang and wàfùtolang). If the stem contained no underlying $\mathrm{H}$, all stem syllables could be expected to receive default L tones. (Since H-spread is domainrestricted in this analysis, no prefixal H's would spread into the stem.)

$\mathrm{H}$

I

Underlying: ni-a-fut-ol-ang-a

$\mathrm{H}$

N

H-Spread $(\rightarrow)$ : ni-a-fut-ol-ang-a

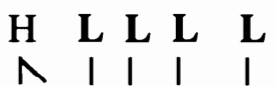

Default Low: ni-a-fut-ol-ang-a

(after EVR): *nafùtòlàng

correct forms: nafùtolang

'I paid a lot' wu-a-fut-ol-ang-a

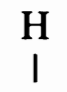

ni-a-ma-mu-fut-ol-ang-a
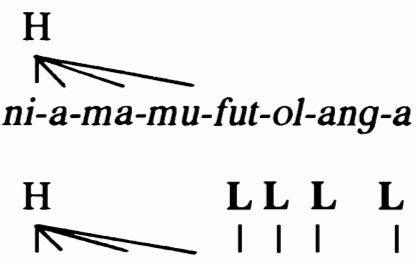

ni-a-ma-mu-fut-ol-ang-a

*namamufùtòlàng

wàfùtolang

'she paid a lot' namàmùfutolang

'I paid him a lot for them'

Also unusable is the idea that the surface tonal difference is attributable to the use in the Near Past of - ang (which could be considered to contribute an underlying $\mathrm{H}$ ) in place of -in (believed to be underlyingly toneless) in the Recent Past. Suffix -ang is too close to the end of the verb to be blocking H-Spread in the prefixal area. In addition, tonal patterns for forms of the Narrative tense turn out to be identical to those in the Near Past, despite the fact that in this case there is no -ang suffix to blame. Compare, for example, forms in the Narrative and Near Past tenses (29). 


$\begin{array}{ll}\text { Narrative } & \text { Near Past } \\ \text { nafùtol } & \text { nafùtolang } \\ \text { namàmùfutol } & \text { namàmùfutolang } \\ \text { wàfùtol } & \text { wàfùtolang } \\ \text { wàmàmùfutol } & \text { wàmàmùfutolang }\end{array}$

'I pay/paid a lot'
'I pay/paid him a lot for them'
'she pays/paid a lot'
'she pays/paid him a lot for
them'

A final idea would be to consider the grammatical $\mathrm{H}$ of the verb stem as linking not to the first stem mora but to the second, and viewing object prefixes as counting as part of the verb stem. This is not an unheard of possibility-a number of Bantu languages have second-mora or second-syllable verb tone linkage, and some count object prefixes as part of the verb stem (though these languages do not usually do this in just one tense). This would seem to generate the forms nafùtolang 'I paid a lot' (with no objects) and namùfutolang 'I paid him a lot' (with one object), since in each case the string of high-toned syllables in the stem starts right after the initial syllable (object prefixes included). Unfortunately, however, this hypothesis has a great deal of trouble handling the form namàmùfutolang 'I paid him a lot for them' with two object prefixes and the form nakàmàmùfutolang 'I went and paid him a lot for them' with two object prefixes and an auxiliary prefix. ${ }^{26}$ Such a view would seem, necessarily, to predict that in a form with two or three prefixes, the final string of high-toned syllables would start with the second prefix from the left (since it is the recipient of the $\mathrm{H}$ of the verb stem), resulting in the incorrect forms *namàmufutolang and *nakàmamufutolang.

26 The auxiliary prefix $k a$ - can be added to most verb forms to add the idea of 'go and....' The third person form corresponding to nakàmàmùfutolang is wàkàmàmùfutolang 'she went and paid him a lot for them.' 
(30) with floating grammatical $\mathrm{H}$ for stem+object domain:

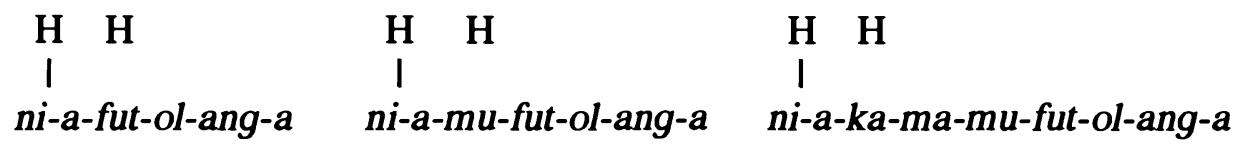

after tone docking (to second mora of stem+object domain):

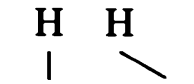

ni-a-fut-ol-ang-a

H-Spread $(\rightarrow)$ :

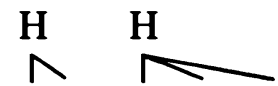

ni-a-fut-ol-ang-a

Default Low:

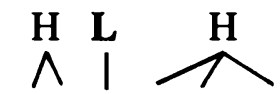

ni-a-fut-ol-ang-a

(after EVR):

nafutolang

'I paid a lot'

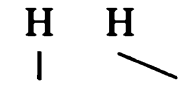

ni-a-mu-fut-ol-ang-a

H

N

$\mathrm{H}$

ni-a-mu-fut-ol-ang-a

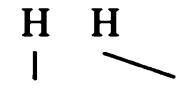

ni-a-ka-ma-mu-fut-ol-ang-a
$\mathrm{H} \quad \mathrm{H}$

N

ni-a-ka-ma-mu-fut-ol-ang-a

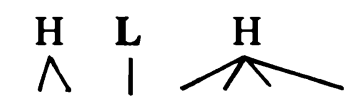

ni-a-mu-fut-ol-ang-a
$\stackrel{\mathbf{H}}{\mathbf{L}}$

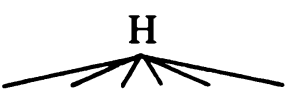

ni-a-ka-ma-mu-fut-ol-ang-a

*nakàmamufutolang

'I went and paid him a lot for them'

The Near Past tense data are difficult for any analysis, as will be seen when the "underlying lows" approach is examined below. Under the "non-shifting underlying highs" analysis, however, the problems appear insurmountable. The central awkwardness of this approach is easily identifiable: like the "shifting underlying $\mathrm{H}$ analysis", it is forced to explain the appearance of surface lows in such first person forms as nakàmàmùfutolang 'I went and paid him a lot for them' and nafuttolang 'I paid a lot' as the result of a toneless gap, the syllables of the gap receiving lows by default at the end of the derivation. However, since tonelessness cannot be directly manipulated by tone rules, and since the only underlying tone is $\mathrm{H}$, the gap (which has variable size and is found in different locations depending upon whether the form has object prefixes or not) can only be created by positing additional H's at the underlying level to block $\mathrm{H}$-spread (the H's themselves possibly coming to be deleted as a result of a rule disallowing H's directly adjacent 
to other H's). While sometimes successful in generating first person forms, adding $\mathrm{H}$ 's to underlying representations (so as to have a means to block spread and leave gaps of tonelessness) usually causes problems in third person forms, which, lacking a high-toned subject prefix, have no means of getting rid of them.

2.3 The underlying $L$ analysis-second look. In its simplest formulation, the underlying lows analysis handles the Recent Past tense data with greater economy than even the non-shifting underlying highs analysis, only a single tone being required at the underlying level. Instead of an $\mathrm{H}$-Spread rule, this approach makes use of a rule spreading $L$ within the prefixal domain.

Underlying: $\quad$ ni-a-ma-mu-fut-ol-in-a

Low Spread:

Default High: (after EVR):

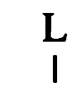

wu-a-ma-mu-fut-ol-in-a

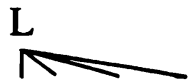

wu-a-ma-mu-fut-ol-in-a

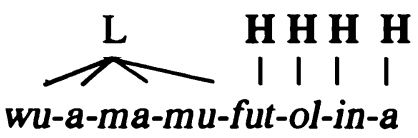

wàmàmùfutodin

'she paid him a lot for them'

However, for reasons which are apparent only when Present Continuous and Near Past data are considered, a better analysis removes the restriction "within the prefixal domain" on L-spread and adopts a cyclic approach in which both L-spread and H-default apply first to the stem-minus final vowel $-a-$ then to the prefixes. (The final vowel will be considered to belong to a "coda" domain, joining the form on the third cycle, where it is subject to a final application of H-default.27) In such an approach, the $\mathrm{L}$ of subject prefix $w u$ - fails to spread into the verb stem because stem syllables are already H-specified by the time prefix-cycle L-Spread applies.

27 Division of the verb into domains of prefix, stem, and final vowel is not uncommon in Bantu phonology, as is evident in the discussion of "layers" in Goldsmith, Peterson and Drogo [1989]. 
(32) stem cycle

L-Spread:

Default-H: prefix cycle
L-Spread:

Default-H: fut ol in

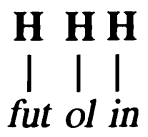

fut ol in

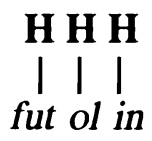

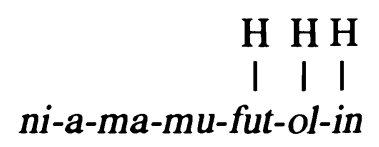

$\mathrm{L}$

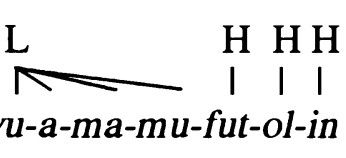

wu-a-ma-mu-fut-ol-in

H $\mathrm{H} \mathrm{H}$

I I I

wu-a-ma-mu-fut-ol-in

\section{HH H H H H H \\ ni-a-ma-mu-fut-ol-in}

coda cycle

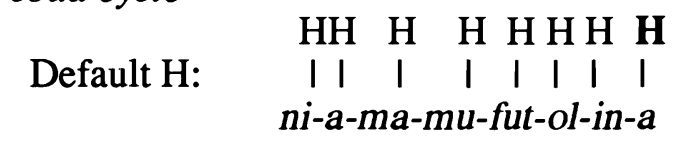

(after EVR): namamufutodin

'I paid him a lot for them'

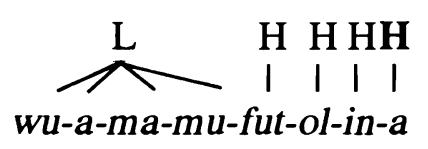

wàmàmùfutodin 'she paid him a lot for them'

In Present Continuous tense forms, the verb stem receives a grammatical low tone which links to the first stem mora. This low, like the low of third person subject prefix $w u-$, is subject to L-Spread, though on the stem cycle. Since the last stem syllable (-in) always surfaces high-toned in Present Continuous forms, this syllable would appear, in this tense, to be "extrametrical" (indicated by angle brackets $<>$ ), meaning that it is invisible to tone rules until extrametricality is lifted. I will assume here that the lifting of extrametricality occurs at the end of a cycle, during the application of the default tone rule. (Since normally only syllables or moras which are at the edge of a domain can be extrametrical, the necessity of marking -in extrametrical is, obviously, one reason for viewing the verb final vowel-which comes after -in—as belonging to a different domain and cycle.) 
(33) stem cycle

Extrametricality:
L-Spread:

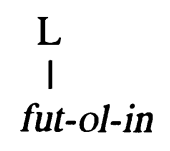

L

fut-ol<in>

L<smiles>[Tl]</smiles>

fut-ol<in>

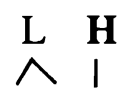

Default-H:

fut-ol-in

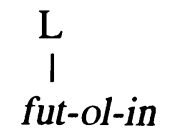

L

fut-ol<in>

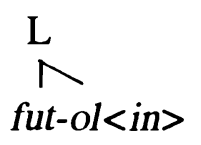

fut-ol-in

Developments in the prefix and coda cycles are as in the Recent Past tense forms.

(34) prefix cycle

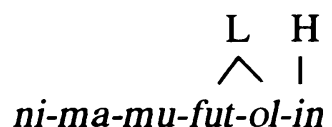

L-Spread:

Default-H:

\section{$\begin{array}{llllllllll}\text { H H } & \mathbf{H} & \mathrm{L} & \mathrm{H}\end{array}$}

ni-ma-mu-fut-ol-in

coda cycle

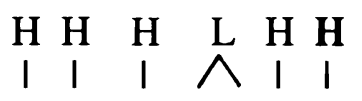

Default H: ni-ma-mu-fut-ol-in-a

(after EVR): nimamufùtòdin

'I am paying him a lot for them'
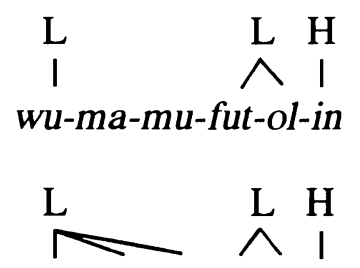

wu-ma-mu-fut-ol-in $\overbrace{w u-m a-m u-f u t-o l-i n-a}^{\mathrm{L}} \underset{\mathrm{I}}{\mathrm{L}} \stackrel{\mathrm{H}}{\mathrm{H}}$

ùmàmùfutòdin

'she is paying him a lot for them'

The derivation of Near Past forms is not nearly so straightforward as for Recent Past and Present Continuous forms. Nevertheless, the possibility of viewing prefix a- as toneless in the Recent Past tense, but as bringing an underlying low to the 
tonal tier in the Near Past tense, provides an explanation for the extra low tones which appear in Near Past forms but not in Recent Past forms, as well as an explanation for the varying location of these lows in forms with object prefixes and those without. If the L brought by a- to the tonal tier is a floating (unlinked) tone, and the first syllable in the prefixal domain is extrametrical, it is not surprising that this $\mathrm{L}$ appears on an object prefix if there is one, and on the verb stem if there is not. Unable to link to any mora in the string-initial extrametrical syllable (since extrametrical syllables are invisible to tone rules), the $\mathrm{L}$ of a- links to the first available mora after that syllable - which in forms with object prefixes belongs to an object prefix and in forms without object prefixes belongs to the initial verb stem syllable.

Linkage of the floating $L$ of a- to object prefixes can be seen in the derivations of forms namàmùfutolang 'I paid him a lot for them' and wàmàmùfutolang 'she paid him a lot for them'. As in the Recent Past tense, L-Spread fails to apply during the stem cycle since the stem is viewed as not having any grammatical tones. All stem syllables consequently receive default H's.

stem cycle

L-Spread:

Default-H:

$$
\text { fut-ol-ang }
$$

fut-ol-ang

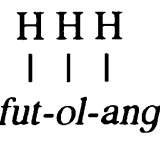

$\mathrm{H} \mathrm{H} \mathrm{H}$

fut-ol-ang

Before the results of the prefix cycle can be shown, an additional rule-aDeletion-must be introduced. As mentioned earlier, the combination of subject prefix and tense-marking prefix a- forms an irregular short vowel. Since exactly when and how the combination vowel comes to be short has not been critical in forms and analyses considered up to this point, this process has not yet been explicitly considered. For the third person form wàmàmùfutolang 'she paid him a lot for them' to be correctly generated under the present analysis, however, it is necessary to view the reduction from two moras to one as occurring prior to the operation of tone rules, and, specifically, as the result of the deletion of the mora of the a-prefix and not that of the subject prefix vowel (36). (The fact that the product vowel has the quality of a-, rather than that of the subject prefix vowel, can be attributed to a rule of assimilation occurring prior to a-Deletion).

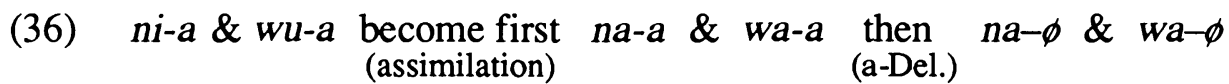


When a-Deletion and extrametricality marking are applied to the forms under consideration, the results are as illustrated in (37).28

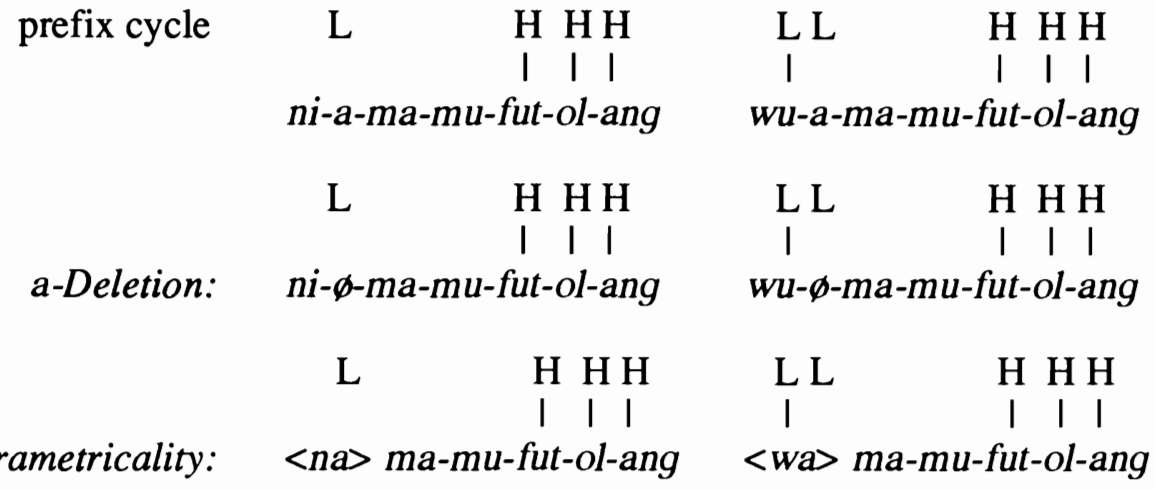

The floating low tone remaining after a-Deletion and Extrametricality can be viewed as docking, by rule, to the first non-extrametrical mora of the string, which in this case is that of object prefix ma-. L-Spread ensures that this tone eventually associates as well to the second object prefix $m u$ -

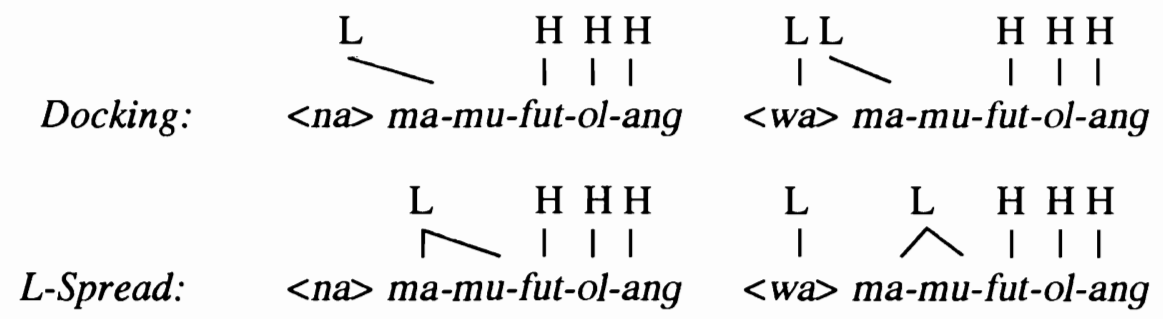

Extrametricality is lifted at the end of the prefix cycle and a default $\mathrm{H}$ assigned to na-. Default-H reapplies during the coda cycle, assigning an $\mathrm{H}$ to the final vowel $-a$.

28 It may have occurred to the reader that the floating quality of a-'s underlying low tone could be viewed as a consequence of a-Deletion. This remains a possibility in Ruwund, though such a view complicates matters somewhat in certain other data sets that cannot, for lack of space, be considered here. The present analysis adopts the floating-from-the-start approach since current theory allows for such, and since though there is some evidence that the tone of $a-$ is not linked at the underlying level (the complications just mentioned), there is nothing at all in the language which suggests that it is linked. 
(39)
Default-H:

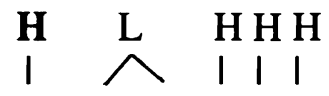

na ma-mu-fut-ol-ang

coda cycle

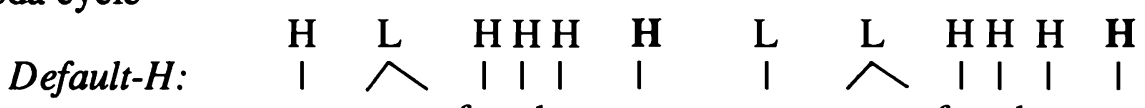

na ma-mu-fut-ol-ang-a wa ma-mu-fut-ol-ang-a

(after EVR): namàmùfutolang wàmàmùfutolang

'I paid him a lot for them' 'she paid him a lot for them'

Derivations for nafùtolang and wàfùtolang begin in a manner identical to those above for namàmùfutolang and wàmàmùfutolang, since they share the same stems.
$\mathrm{H} \mathrm{H} \mathrm{H}$
H H H
I I I
I I I
(at end of stem cycle): fut-ol-ang
fut-ol-ang

When a-Deletion and extrametricality are applied, the result is as follows.

L $\mathrm{HH} \mathrm{H}$

(input to

prefix cycle):

ni-a-fut-ol-ang

L $\mathrm{H} \mathrm{H} \mathrm{H}$

a-Deletion: na- $\varnothing$-fut-ol-ang

L $\mathrm{H} \mathrm{H} \mathrm{H}$

l I I

Extrametricality: <na> fut-ol-ang

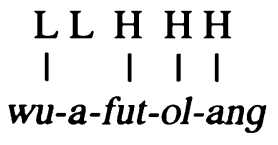

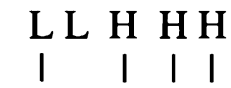

wa- $\varnothing$-fut-ol-ang

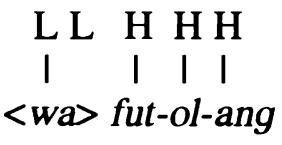

It is now time for "Docking" to apply, but in these forms, the "first nonextrametrical mora of the string" belongs to $u$ of the stem -futolang rather than to any object prefixes. As $u$ of $-f u t$ is already linked to an $\mathrm{H}$, it will be necessary to view the Ruwund docking rule as providing associations for floating tones even when target moras are already linked to other tones. Note, however, that the subsequent failure of the $\mathrm{L}$ on a- to appear on more than one syllable on the surface (as it does, say, in nakàmàmùfutolang 'I went and paid him a lot for them') is now explained: unlike object prefixes, stem syllables are not toneless but rather linked 
to H's as a result of stem-cycle Default-H. L-Spread provides for the spread of an $\mathrm{L}$ only to additional toneless moras; it cannot spread an L through a string of $\mathrm{H}$ 's.

(42)

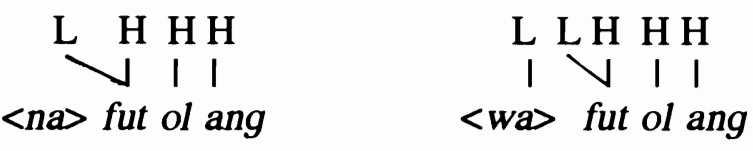

L-Spread:

Extrametricality is lifted at the end of the prefix cycle and a default $\mathrm{H}$ assigned to na-. Default- $\mathrm{H}$ reapplies during the coda cycle, assigning an $\mathrm{H}$ to the final vowel $-a$.

$$
\text { H L H H H }
$$

I $\vee$ I I

Default-H: na fut-ol-ang

coda cycle

Default-H:

HL H HH H

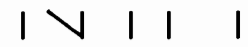

na fut-ol-ang-a
L L H H H H

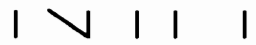

wa fut ol ang a

To complete these derivations, another rule, which I shall call Rising Tone Simplification (RTS) \#1, is required. During RTS\#1, a syllable which is linked to both an $\mathrm{L}$ and an $\mathrm{H}$ on the tonal tier, yet followed by an $\mathrm{H}$-linked syllable, becomes simply L-linked.

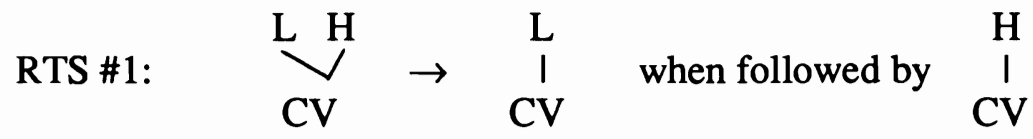

Application of RTS\#1 produces the correct surface forms for the present derivations. (The rule has, of course, no effect on the other derivations provided under this analysis since they contain no rising tones.) 
End Vowel Rules:

$\begin{array}{lll} & \text { H L H H } & \text { L L H H } \\ \text { RTS \#1: } & \text { na fut-ol-ang } & \text { wa fut-ol-ang } \\ & \begin{array}{ll}\text { nafùtolang } \\ \text { 'I paid a lot' }\end{array} & \begin{array}{l}\text { wàfùtolang } \\ \text { 'she paid a lot' }\end{array}\end{array}$

wa fut-ol-ang

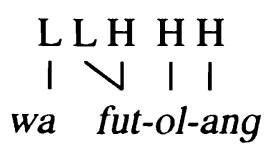

HL H H H
I $\mathrm{V}$ । I
na fut-ol-ang

This analysis of Near Past verb forms is strongly supported in that there exists excellent evidence that the initial stem syllable - fu- really does bear a rising tone just prior to its realization on the surface. In addition to Rising Tone Simplification \#1, Ruwund also has Rising Tone Simplification \#2, ordered after RTS \#1,29 which simplifies a rising tone following a low tone to high. Rising Tone Simplification \#3, also ordered after RTS \#1, simplifies a rising tone following a high tone to "high-toned preceded by a downstep". 30 The three RTS rules-all of which are well motivated by other data in the language 31 _explain effortlessly the slightly different surface patterns that are found in Narrative tense forms with monosyllabic stems. As can be seen below, Narrative tense forms for multi-syllabled stems are identical to Near Past tense forms except that they lack suffix -ang.

29 As the Rising Tone Simplification rules all apply to different environments, an alternative to ordering the rules is to add the condition "before L or a word boundary" to rules \#2 and \#3.

30 Downstep - the abrupt lowering of the pitch range between two high-toned syllables (caused, it is usually assumed, by a floating low tone) - is a common phenomenon in Bantu.

31 Note, for example, that the rising tone of the Narrative tense form wŏsh (wù-a-osh-a) 'she burns' simplifies (by RTS \#1) to low in wòshol 'she burns a lot' (where high-toned -ol is added to the stem), and that the rising tone of relative form nǒsha (nì-a-osh-à:) 'which I burn' simplifies (by RTS \#2) to high in equivalent form mìnoshà (which includes optional relative preprefix mì-). 
(46) Narrative Tense

nafùtol

'I pay a lot'

wàfùtol

'she pays a lot'

nakàmàmùfutol

'I go and pay him a lot for them'

wàkàmàmùfutol

'she goes and pays him a lot for them' 'she went and paid him a lot for them'
Near Past Tense

nafùtolang

'I paid a lot'

wàfùtolang

'she paid a lot'

nakàmàmùfutolang

'I went and paid him a lot for them'

wàkàmàmùfutolang

When, however, the verb -futol 'pay a lot' is shortened to just - fut 'pay', RTS\#3, rather than RTS\#1, applies to 'I pay' and RTS\#2 (rather than RTS\#1) to 'she pays', with the result that -fut surfaces with a high tone in these forms. 32

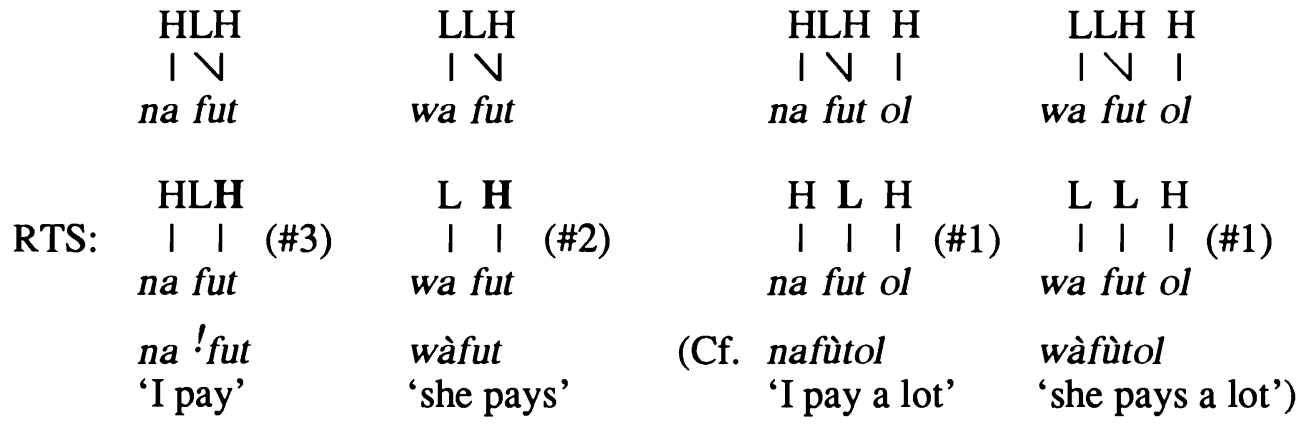

Otherwise highly problematic, the three-way tonal alternation-low, high and downstepped high - of stem-initial syllable - fut in Narrative and Near Past tense forms can be considered a natural, melody-preserving consequence of contourtone reduction if the initial stem syllable is viewed as at some point bearing a rising tone. 33 Since the rising tone has a logical explanation under an analysis employing

32 No stem tone changes are found in the Narrative forms nakàmàmùfut 'I go and pay him' and wàkàmàmùfut 'she goes and pays him,' since in such forms the underlyingly toneless auxiliary and object prefixes are the recipients of a low tone from a- and no rising tones are ever created in the stem.

33 It is critical that the floating low tone brought by the tense-marking prefix a- link to the hightoned verb stem to create a rising tone prior to the lifting of extrametricality of the low-toned initial syllable wa- in third person forms. If this tone remained floating, it would be expected to simply merge with the adjacent linked low of wa- as soon as that morpheme joined the string. The syllable -fu- in wàfùtolang - which is high-toned at the end of the stem cycle-would consequently never be affected by it, and would fail to surface with a low-tone. An alternative hypothesis in which the low often appearing on the initial stem syllable is a grammatical one 
underlying L's, extrametricality and cyclic rule application, but is very difficult to generate consistently under other hypotheses, the Narrative tense data must be considered strong evidence in favor of this approach.

\subsection{Summary}

Of the three analyses considered, only the "underlying L's" approach satisfactorily accounts for basic verb forms in all three trial tenses. The possibility-available only in an "underlying L" approach-of viewing tense-marking prefix a- as bringing a floating low tone in the Near Past tense explains the otherwise mysterious appearance of low tones in first person forms right after the subject prefix (on object prefixes, or in forms lacking these, on the first verb stem syllable). Furthermore, this analysis naturally derives rising tones on the initial syllables of Near Past and Narrative tense verb stems, and thus allows the divergent surface tone patterns of short-stem Narrative forms to be an automatic consequence of independently-motivated rules in the language simplifying rising tones. Although data from the Future and Distant Past tense groups were not considered in the process of eliminating the $\mathrm{H}$-based approaches, they are entirely consistent with the view that in Ruwund, $\mathrm{L}$ rather than $\mathrm{H}$ is underlying. 34

assigned to the stem by the tense, but allowed to link to it only in cases where the first stem syllable is not also the final stem syllable (in which case it could be viewed as being extrametrical and consequently unavailable for tone docking), is unable to account for the Near Past forms nafùtolang 'I paid a lot' and wàfùtolang 'she paid a lot'. Under such an approach, a stem-assigned grammatical low would be expected to spread (as a consequence of the L-Spread rule) to -ol, producing *nafùtòlang and * wàfùtòlang (paralleling the Present Continuous forms nifùtòdin 'I am paying a lot' and ùfütòdin 'she is paying a lot').

34 The Ruwund Distant Past tense is similar to the Present Continuous in that a low tone is assigned to the verb stem and spreads there (if the stem is multimoraic). The two tenses are dissimilar in that in the Distant Past, 1) the tense-marking prefix -a- accompanies the subject prefix, 2) all subject prefixes are underlyingly toneless, 3) the last stem syllable is not extrametrical, and 4) the final vowel is underlyingly long and, thus, is not eliminated by EVR but only shortened.

\section{namamufùtòla 'I paid him a lot for them' wamamufùtòla 'she paid him a lot for them'}

Ruwund future tenses employ only a subject prefix, tense-marking prefix $\mathrm{ku}$-, and the verb stem (followed by a non-surfacing final vowel). A unique and interesting feature of this tense group is that the spread of the low tone of third person subject prefixes is in this case dependent upon metrical structure, a prefixal low tone being able to spread only within its metrical foot. Since binary feet are constructed right to left throughout the prefix domain beginning at the juncture of prefixes and stem, the effect is to permit spread in cases where there is an even number of moras in the prefixal domain (as in (b) and (f) below), and to prohibit it when the total number is odd (the subject prefix ending up alone in its foot), as in (d). 
It is not difficult to state in general terms why an L-based analysis succeeds and $\mathrm{H}$-based analyses fail. In Ruwund, it turns out that it is low tones, rather than high tones, that appear in consistent patterns throughout many verb forms and that can readily be tied, by virtue of their position, to specific morphemes in verb strings. In contrast, high tone patterns are difficult to characterize and defy linkage to morphemic components.

$\mathrm{H}$-based analyses struggle hopelessly with these facts. On one hand, they are forced to employ very general $\mathrm{H}$-spread rules to account for the many all-high words in the language. On the other hand, they must also posit multiple underlying $\mathrm{H}$ tones in order to generate the often multi-syllabic strings of low tones in Ruwund verb forms, relying on the spread inhibition or deletion-triggering potential of these H's to create or maintain multi-syllabled gaps of tonelessness (that eventually undergo default- $\mathrm{L}$ tone assignment). Hence, $\mathrm{H}$-based analyses represent awkward attempts to access the low-toned areas in verbs-which, as just pointed out, are in themselves relatively characterizable —only by the very indirect means of positing multiple underlying H's in not-so-characterizable $\mathrm{H}$-toned areas. The result is invariably too many H's on the surface; the underlying $\mathrm{H}$ tones posited to generate toneless gaps in some verb forms inevitably surface where they shouldn't in other, closely related forms.

Unlike an H-based analysis, an L-based approach can access low-toned areas in verb forms directly, since it manipulates low tones from the start. Surface low tones and low tone sequences can be generated by viewing certain pivotal morphemes (e.g., third person subject prefix wu- and tense marker a-) as bearing underlying L's, and by employing a spread rule affecting only moras within natural verbal domains. Rather than view the "generality" and "non-definability" of the many surface high tones as the product of a very general spread rule, the L-based approach permits this to be a simple reflection of "elsewhereness", as captured in such an analysis by the relegation of $\mathrm{H}$ to default status.
(a) nikufutol
'I will pay a lot'
(c) nikumufutol
'I will pay him a lot'
(e) nikumamufutol
'I will pay him a lot for them'
(b) ùkùfutol (w/spread), foot: (ùku) 'she will pay a lot'
(d) ùkumufutol (no spread)
'she will pay him a lot'
(f) ùkùmamufutol (w/spread)
feet: (ù) (kumu)
feet: (ùku) (mamu)

An additional interesting feature of the future tenses is that a low tone is assigned to the verb stem just in cases where the stem is monomoraic, as exemplified by the following forms for -fut 'pay:'
nikumufùt
'I will pay him'
ùkumufùt
'she will pay him'

(cf. the forms for -futol 'pay a lot' above, as well as nikumukwaash 'I will help him' and ùkumukwaash 'she will help him,' where no low tone is assigned since stem - $k$ waash is bimoraic) 


\subsection{Meeussen's Rule}

As Meeussen's Rule (the deletion of a high tone after another high tone) is a feature of a number of Bantu tone systems, an immediate question of interest is whether Ruwund-which employs underlying L's instead of underlying H'smakes use of a rule of this type deleting lows after lows. The answer is that Meeussen's Rule is found in Ruwund, though in limited contexts. ${ }^{35}$ In verb forms, for instance, it affects only a low-toned final vowel and other low-toned morphemes of the verb's "coda" domain.36 An example that is not too involved to be presented here can be found in the Habitual Past and Distant Past tense forms of (48) below. Note that the final vowel is low-toned in forms (b), (c) and (d)-where it follows the high-toned morphemes -aañ and -ang - and high-toned in (a) where it follows the low-toned morpheme -òl.

Distant Past

(a)

'I paiùtòla

(b) nakufùtòlaañà

'I paid you(pl) a lot'
Habitual Past (=Dist. Past + -ang)

(c) nafùtòlangà

'I used to pay a lot'

(d) nakufùtòlang! aañàa

'I used to pay you(pl) a lot'

$(k u \quad \ldots$ aañ $=2$ p obj.pfx. $k u$ - and plural sfx. -aañ ; - ang = habitual action sfx. $)$

The behavior of -à/a in these two closely-related tenses suggests that for this tense group, the final vowel is both underlyingly long and underlyingly low-toned. If - $a$ /a is long underlyingly, its appearance on the surface is understandable, since the End Vowel Rules can be viewed as shortening rather than eliminating long vowels. If it is underlyingly low-and made subject to Meeussen's Rule - the tonal alternation in the above forms (and many others where an -à/a alternation appears) is also explained: the final vowel's underlying $\mathrm{L}$ is deleted by Meeussen's Rule when it directly follows morphemes linked to low tones (such as stem morpheme -òl 'a lot' in the example above), yet free to surface otherwise.

Supporting the view that final vowel -à/a in these tenses is underlyingly lowtoned and subject to Meeussen's Rule is the fact that certain adverbs which are

35 Note that Meeussen's Rules does not, for instance, delete the L of the verb stem in the Present Continuous tense when this follows directly the $\mathrm{L}$ of prefixes in 3rd-person forms (as is clear from ùmàmùfütòdin 'she is paying him a lot for them,' derived earlier).

36 As mentioned earlier, the underlying $\mathrm{L}$ analysis views a verb's final vowel as belonging to a third subdivision in the verb string, here referred to as the "coda" domain. In addition to final vowels, it contains object suffixes, habitual-action suffix -ang, and plural suffix -aañ, of which only object suffixes are potentially low-toned underlyingly and consequently subject to Meeussen's Rule. 
normally preceded by a downstep when they adjoin themselves to words ending in high-toned syllables, lose their downsteps when adjoined to verb forms where this final vowel has also lost its low. The adverb 'kand 'again' is an example (49).
no loss of downstep:
nzal-!'kand
'hunger again'
nifùtòdin-!kand
'I am paying a lot again'
loss of downstep:
nafùtòla-kand
'I paid a lot again'

Since downstep is caused by a floating low tone, the loss of the adverb's downstep in this environment can be seen as the consequence of its coming directly after an underlying low belonging to the verb final vowel -à/a. Either the floating low of !kand simply merges with the underlying low of -à/a prior to this tone's deletion via Meeussen's Rule, 37 or, in an alternative view, Meeussen's Rule applies twice, first deleting the floating low of $!^{k}$ and (since it follows -à) and then deleting the low of -à (since it follows -òl).

An example of Meeussen's Rule outside of verbs can be found in the predicative forms of nouns. Although predicatives are complex and by no means completely understood, it is clear that they minimally involve adding a low tone to a noun's initial mora. The noun rusûc 'hair' thus becomes rùsûc 'it is a hair' and nzal becomes ǹzal 'it is hunger'. However, when this low is added to a noun with a second-syllable low tone, the second-syllable low-and, in certain circumstances, a subsequent low in the phrase-is lost. The low of -kìl in mukil 'tail' is lost, for example, in predicative mùkila 'it is a tail', as are also the initial lows of nàmànangà 'that I saw' in predicative mùkil namanangà 'it is a tail that I saw', the low of the associative particle wà of wà kafùr 'of the turtle' in predicative mùkil wa kafùr 'it is the tail of the turtle', and the downstepping floating low of demonstrative ! wa in predicative mùkil wa 'it is that tail'.

\subsection{Historical Perspective}

Though the choice of a synchronic analysis shouldn't depend on the researcher's ability to trace its historical development, finding a reasonable historical explanation can lend credibility to any claims made concerning the nature of the contemporary phonological system, especially if, as in the case of Ruwund, the language is found to be very different from other members of its family and from its supposed ancestor. If Ruwund has an underlying L/toneless contrast instead of the $\mathrm{H} /$ toneless one found in most Bantu languages (and believed to be characteristic of Proto-Bantu)-a development which constitutes "reversal" at a

37 Since they are adjacent on the tonal tier, it would not be expected that the floating low tone of the adverb would maintain an existence separate from that of the linked underlying low of -àda. 
very deep level-it would certainly be desirable to be able to propose how the former evolved from the latter.

Examining data from Ciluba, Maddieson (1976) proposed that the inverse tone patterns of that language resulted from two historical developments: the introduction-at a time when Ciluba still used nominal pre-prefixes-of an iterative rule spreading any tone, $\mathrm{L}$ or $\mathrm{H}$, one mora to the right if that mora was followed by a word boundary or by a mora associated to a non-contrasting tone, 38 and later, the loss of nominal pre-prefixes resulting in a shift of all tone melody elements one mora to the right. These developments are shown in the derivational table in (50) below, an adaptation of one of Maddieson's own. If just the tone of the nominal prefix (cv) and the various nominal roots (CV and CVCV) are considered, clearly the "new" tonal associations are the inverse of the original ones.

(50) original tonal associations:

\begin{tabular}{|c|c|c|c|c|c|c|}
\hline noun type: & $\# 1$ & $\# 2$ & $\# 3$ & $\# 4$ & $\# 5$ & \#6 \\
\hline & $\begin{array}{lll}H & \mathrm{~L} & \mathrm{H} \\
\mathrm{I} & \mathrm{I} & \mathrm{I} \\
\mathrm{vcv} & \mathrm{CV}\end{array}$ & $\begin{array}{l}\text { H L L } \\
\text { I I I I } \\
\text { vevCV }\end{array}$ & $\begin{array}{cccc}\mathrm{H} & \mathrm{L} & \mathrm{H} & \mathrm{L} \\
\mathrm{I} & \mathrm{I} & \mathrm{I} & \mathrm{I} \\
\mathrm{vevCV} & \mathrm{CVV}\end{array}$ & 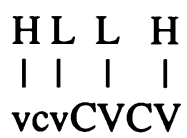 & 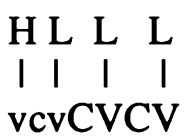 & $\begin{array}{cccc}\mathrm{H} & \mathrm{L} & \mathrm{H} & \mathrm{H} \\
\mathrm{I} & \mathrm{I} & \mathrm{I} & \mathrm{I} \\
\mathrm{vcvCV} & \mathrm{C}\end{array}$ \\
\hline
\end{tabular}

first historical development:

spread: HL L HHL HL H H HHL H HH L L

(1st appl.) vevCV vevCV vevCVCV vcvCVCV vevCVCV vevCVCV

(2nd appl.) $\quad$ vevCV

H H H

I I I

(3rd appl.)

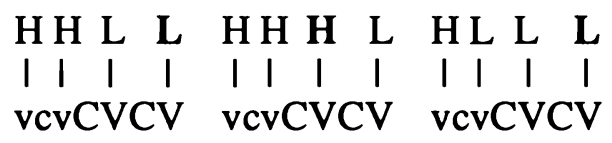

H H H L

I I I I

vcvCVCV

38 As Maddieson's article was written before the advent of autosegmental tonal analyses, I have rephrased the rule somewhat. In its original form, the rule "changes a tone to the same as a preceding tone of opposite value, when a tone of the same value or a word boundary follows." 
second historical development:

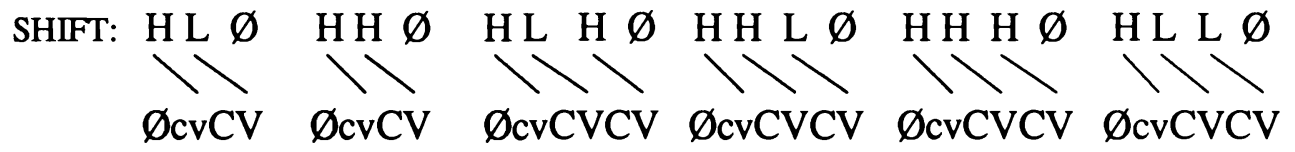

new tonal associations:

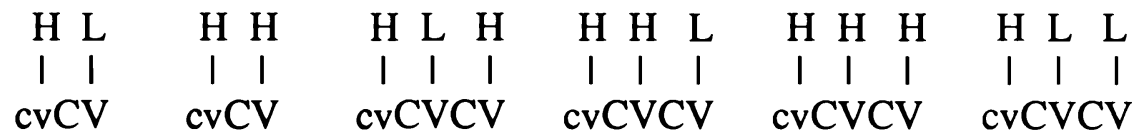

Though an inspired explanation at the time, Maddieson's account is not easily modified to fit developments in tone theory since the article appeared. Leaving aside the fact that Maddieson uses underlying H's and L's, rather than an " $\mathrm{H}$ (or L) vs. toneless" underlying contrast, there is a major problem in the spread rule. In an autosegmental analysis, the initial H of an H-L-L-L sequence (as in Maddieson's nominal type \#5) could not spread throughout the L's to produce eventually $\mathrm{H}-\mathrm{H}-$ $\mathrm{H}-\mathrm{H}$. When two tones are present (which is the case only after low default tone insertion in an $\mathrm{H} /$ toneless approach), spread is necessarily a two-step process. It begins with the association of a tone to a segment linked to another tone, and concludes with the delinking of that segment from its original tone.

(51)

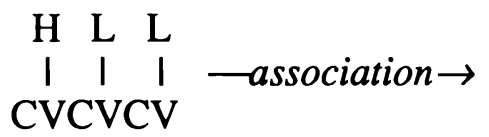

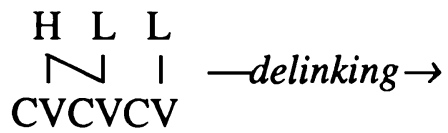

Two-step processes, however, cannot be iterative in standard, non-cyclic rule systems. ${ }^{40}$ In an ordered rule system, there can be no reapplication of an earlier rule (such as "association") after another rule (such as "delinking") has applied. The multi-syllable spreads of tones in some Bantu languages are, thus, usually accounted for in the manner illustrated in the various analyses for Ruwund tested earlier in this paper: an underlying tone spreads iteratively to a number of toneless syllables-before a default tone rule has applied. Unfortunately, though a spread mechanism of this type would work for Maddieson's \#5 type nouns (assuming that

39 A superscript $L$ is used here to indicate that the floating $L$ left after delinking would not be expected to remain a separate tone on the tier since it is followed by another $\mathrm{L}$, linked to the segmental tier.

40 Though multi-step processes can be iterative in cyclic approaches, a cyclic analysis which added just one syllable per cycle would be difficult to justify for Bantu languages where natural domains (prefixes, roots, etc.) are often polysyllabic. 
the moras marked $\mathrm{L}$ in (50) above are considered to instead be toneless), it would fail in the case of type \#6 nouns, since there it is L-the presumed default valuewhich would need to spread. 41

As Maddieson pointed out, reversal would not have been a sudden development. To restate this in terms of the analysis developed here for contemporary Ruwund, speakers could not very well have simply one day changed the underlying tonal specification from high to low and inverted all of their pronunciations. There would, instead, have been a series of gradual phonetic developments that led to a stage at which two different analyses were possible, both producing the same phonetic result. At some point in Ruwund's history, adults must have been employing a system based on underlying highs, while children learning the language were interpreting what they heard as a system based on underlying lows. Certain peculiarities in the way in which tones are actually realized phonetically in Ruwund today suggest an historical scenario quite different from that proposed by Maddieson for Ciluba-one, in fact, making use of leftward spread rather than rightward spread.

Pitch differentiation is a subtle matter in contemporary Ruwund. The pitch range employed is very narrow to begin with, and the language makes use of a rule of "High Tone Lowering" which further reduces surface differences by causing all high tones not immediately followed by lows to be realized with mid pitch rather than high pitch. High Tone Lowering can be considered to belong to a nonstructure-changing "phonetic implementation" level in the phonology. As is evidenced by the phrases below, it is operative across word boundaries within a breath group. 42

- Phrases where all-high-toned noun cindaal 'scabbard' is not followed directly

by a low tone and is thus realized with a mid/mid melody (both syllables being subject to High Tone Lowering):

$\begin{array}{lc}\text { cindaal (isolation) } & \text { 'scabbard' } \\ \text { cindaal cilemp } & \text { 'long scabbard' } \\ \text { cindaal capà Iika } & \text { 'the scabbard fell' } \\ \text { cindaal nimpaka } & \text { 'the scabbard and the knife' } \\ \text { (phonetic tone realization for cindaal : } \text { mid/mid) }\end{array}$

41 Following application of the default rule, there are, of course, no remaining toneless vowels to be recipients of spread, so the problems are the same as for Maddieson's original account using both highs and lows at the underlying level.

42 Ciluba also has this rule, as can be seen, for example, in the contrast between the phrases cilamba [mid/mid/mid] cibì 'bad bridge' and cilamba [mid/mid/high] cà kawungej̀ 'Kawungeji bridge'. Preliminary evidence indicates that it is characteristic of at least two other "reversing" languages - Southern Kete and Kanyok-as well, suggesting a correlation between reversal and High Tone Lowering. 
- Phrases where cindaal is followed by a low tone and thus realized with a mid/high melody (only initial syllable $c i$ - being subject to High Tone Lowering):

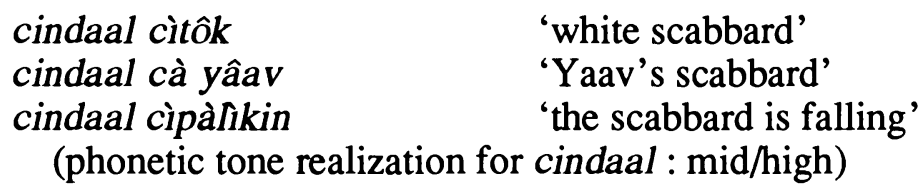

A second important feature of Ruwund phonetic implementation is "Abrupt Fall"- a rule which causes a low-toned syllable which directly follows a hightoned one in the same word to be realized with a special, quick-falling pitch pattern (phonetically distinct from the more gradual high-falling pitch pattern of a genuine falling-tone syllable such as those in ût 'bow' and nsûc 'hair'). Unlike High Tone Lowering, Abrupt Fall is operative only word-internally.

High Tone Lowering and Abrupt Fall cause the five nouns considered earlier in this paper to have the following isolation pronunciations:

(52)

$\begin{array}{lllll}\mathrm{H} & \mathrm{HL} & \mathrm{H} \mathrm{H} & \mathrm{HL} & \mathrm{H} \mathrm{HL} \\ \text { I } & V & \text { I I } & \text { I I } & \text { I V } \\ \text { muj } & u t & \text { nzal } & \text { mukil } & \text { nsuc } \\ \text { muj } & \hat{u t} & \text { nzal } & \text { mukil } & \text { nsûc } \\ \text { [mid] } & \text { [high-falling] } & \text { [mid-mid] } & \text { [high-abrupt falling] [mid-high-falling] } \\ \text { 'root' } & \text { 'bow' } & \text { 'hunger' } & \text { 'tail' } & \text { 'hair' }\end{array}$

I will return to these eventually, but would like now to propose that the ancestor to contemporary Ruwund, Proto-Ruwund, had nouns with 1) surfacing final vowels, 2) underlying and surface tone like that of Proto-Bantu, and 3) completely straightforward phonetic realization of tone. In close resemblance to the ProtoBantu system proposed in (12), the Proto-Ruwund system could have been as in (53).

(53) underlying:

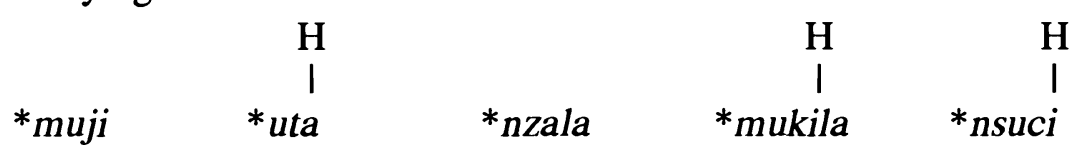

with low default tones:

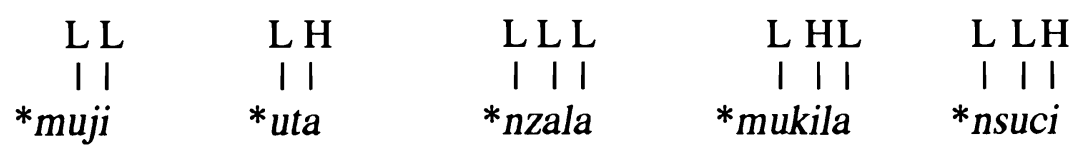


phonetic realization:

low-low low-high low-low-low low-high-low low-low-high

Now, if to this system were eventually added (prior to Default-L) an assimilatory rule of High Anticipation (i.e., high spread leftward), whereby a high tone spreads to the preceding syllable and causes it also to be associated to an $\mathrm{H}$ (and thus realized high), the result would be as in (54).

(54) underlying:

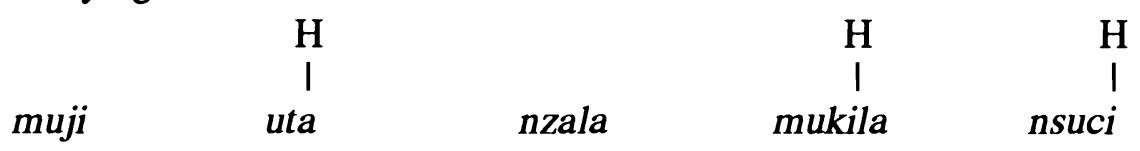

after $\mathrm{H}$ leftward spread (High Anticipation):

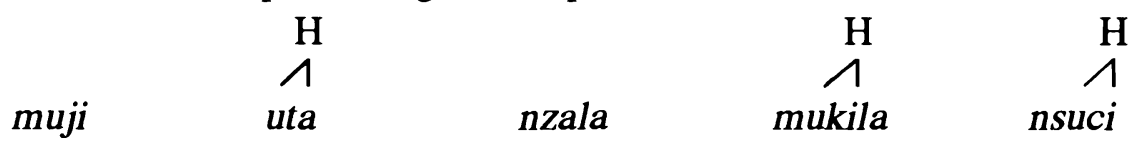

with low default tones:

\begin{tabular}{|c|c|c|c|c|}
\hline L L & $\mathrm{H}$ & $\mathrm{L} \mathrm{LL}$ & $\mathrm{H} \mathrm{L}$ & \\
\hline 11 & $\wedge$ & 111 & $\wedge 1$ & \\
\hline muji & uta & nzala & mukila & nsu \\
\hline
\end{tabular}

phonetic realizations:

low-low high-high low-low-low high-high-low low-high-high

Suppose now that, after a time, speakers of this version of Ruwund began to realize the second syllable of a pair of high-toned syllables (the right branch of a branching high tone) with a falling pitch pattern, and, perhaps a little later, developed a tendency to realize purely low-toned syllables at a slightly higher pitch than the low point of a falling pitch pattern. ${ }^{43}$ The changes-which represent only the addition of some "phonetic implementation" rules to the grammar and have no effect upon structure-could have occurred quite gradually, with the falling pitch becoming more and more pronounced until it became the most

43 The falling pitch pattern itself could have begun as assimilation in words like *múkilà (where the second high is followed by a low) and later been generalized to all cases where there was a branching high tone. 
prominent pitch pattern phonetically, and with the low tones slowly coming to have more mid-like realizations. ${ }^{44}$ Pronunciations would have been as in (55).

(55)

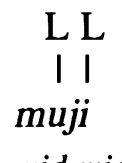

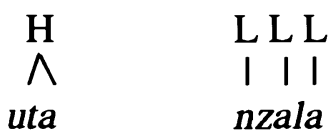

high-falling

mid-mid-mid

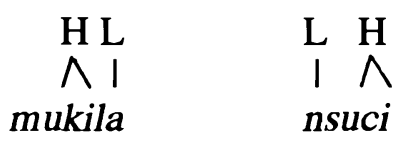

high-falling-mid mid-high-falling

This phonetic result, however, could have easily been reanalyzed by the next generation as reflecting a different structure with different realization rules: one which views falling pitch as a realization of $\mathrm{L}$, and mid and high-pitched syllables as two different realizations of $\mathrm{H}$ (high before $\mathrm{L}$, mid elsewhere).

(56)

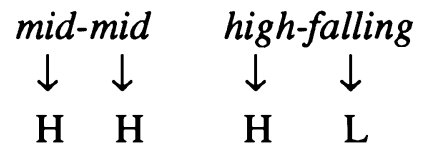

mid-mid-mid

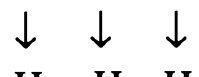

$\mathrm{H} \quad \mathrm{H} \quad \mathrm{H}$ high-falling-mid<smiles>[AlH]C1CC1</smiles>

$\mathrm{H} \quad \mathrm{L}$

mid-high-falling

(57) reinterpreted structure:

$\begin{array}{ccccc}\text { H H } & \text { H L } & \text { H H H } & \text { H L H } & \text { H H L } \\ \text { I I } & \text { I I } & \text { I I I } & \text { I I I } & \text { I I I } \\ \text { muji } & \text { uta } & \text { nzala } & \text { mukila } & \text { nsuci }\end{array}$

With this interpretation of tonal structure, the leap to the view that $L$ is underlying and $\mathrm{H}$ inserted by default is virtually automatic, since such an assumption provides the most economic analysis. The relatively few L's become the locations in underlying representations "marked" for underlying tone, and the numerous H's become the "elsewhere" default tone. The "High Anticipation" rule disappears. Though the "phonetic implementation" component of the grammar is quite different for the children than for their parents, the new realization principles - that an $\mathrm{H}$ not preceding an $\mathrm{L}$ is realized with mid pitch and an $\mathrm{L}$ after an $\mathrm{H}$ with falling pitch-are no more numerous, complicated or unnatural than the old ones.

44 Even in contemporary Ruwund, syllables bearing abrupt-falling pitch patterns have a certain accent-like prominence, and as observed earlier, the overall pitch range employed is not very wide. 
(58) children's new underlying forms:
$\begin{array}{rrrrr} & \text { L } & & \text { L } & \text { L } \\ & \text { I } & & \text { l } & \text { I } \\ \text { muji } & \text { uta } & \text { nzala } & \text { mukila } & \text { nsuci }\end{array}$

after Default-H insertion (=new structures):

$\begin{array}{ccccc}\mathrm{HH} & \mathrm{HL} & \mathrm{H} \mathrm{HH} & \mathrm{H} \mathrm{LH} & \mathrm{H} \mathrm{H} \mathrm{L} \\ \text { I I } & \text { I I } & \text { I I I } & \text { I I I } & \text { I I I } \\ \text { muji } & \text { uta } & \text { nzala } & \text { mukila } & \text { nsuci }\end{array}$

phonetic realization:

mid-mid high-falling mid-mid-mid high-falling-mid mid-high-falling

As in the $\mathrm{H}$-based analysis of their parents, children employing this system would have underlying tone differences occurring where they should-on the various stem syllables rather than on prefixes - and be exploiting all possible tonal possibilities for stems (except that, as in the original system, no forms have an underlying tone linked to two moras). The site of the underlying tone, in fact, has not changed. However, since that syllable has come to be realized with a falling pitch pattern, what it is- $\mathrm{H}$ or $\mathrm{L}-$ from the structural standpoint has become open to interpretation. The older speakers know it as the original source of a spreading and slightly corrupted $\mathrm{H}$, while the younger speakers see it rather as a somewhat deformed L. Both analyses could easily coexist for a short while within the same community.

To return now to contemporary Ruwund, it is easy to see that the pronunciations just derived above for an older Ruwund could evolve into the present ones (repeated below) when final vowels began to be devoiced and deleted. Devoicing created a new structural type: the syllable with a "true" falling tone (i.e., one that is linked to both an $\mathrm{H}$ and an $\mathrm{L}$ on the tonal tier as a result of the backward reassociation of a stranded final $L$ ). The new structure was realized, as would be expected, with a falling pitch, but one sufficiently distinct from the type of falling pitch already in use for a low-toned syllable which follows a high tone to ensure that these two types of syllables remained distinguishable. The difference (a highstarting, gradual fall vs. a mid-starting, very abrupt fall) is that which remains discernible today.
(59) $\quad \mathrm{H} \quad \mathrm{H} \mathrm{L}$
$\underset{\mathrm{H}}{\mathrm{H}}$
H L
muj ut
nzal
mukil
H H L
nsuc
muj $\quad \hat{u}$
nzal mukì
nsûc
[mid] [high-falling]
[mid—mid] [high—abrupt-falling]
[mid-high-falling] 
Though it is difficult to apply this scenario directly to verb forms-especially if today's verb form patterns with their long strings of low tones are used as a starting point--this should not be regarded as a catastrophic defect of the hypothesis. Verbal tone is undoubtedly the single most unstable aspect in all of Bantu phonology, as is evidenced by the great variety of contemporary systems found, and the present Ruwund system is neither very old nor likely to survive long into the future. 45 Ruwund nouns could conceivably have changed first, with verbal patterns making changes as necessary to keep up.

\subsection{Conclusion}

This discussion has argued, through a consideration of basic nominal tone patterns and the tonal characteristics of verb forms in three tenses, that Ruwund makes use of an underlying $\mathrm{L} /$ toneless contrast, as opposed to the usual Bantu H/toneless one. Low tones, rather than high tones, are found to occur in morphologically critical and definable locations, and it is $\mathrm{L}$ which is subject to such basic and common tone rules as spread and deletion. The relegation of high tones to default status is also found to be natural, given the very general "elsewhere" nature of their distribution in this language. These findings are theoretically significant in that by being most conducive to an analysis where low tones are underlying and high tones inserted only by default, Ruwund constitutes a counterexample to the Pulleyblank proposal that in two-tone languages, $\mathrm{L}$ is always the default value. Clark's suggestion that a $\mathrm{H}$-based systems with $\mathrm{L}$ default rules be considered as representing merely the "unmarked" case-rather than the sole possibility-is thus strongly supported.

Ruwund's changing of the underlying specification from $\mathrm{H}$ to $\mathrm{L}$, while still maintaining in nouns a distribution of underlying tone virtually identical to that in reconstructed Proto-Bantu, establishes that, at least for this language, the term "reversal" is not a misnomer. That such a major change can indeed be explained from the diachronic standpoint is shown through the presentation of a plausible historical account for Ruwund, in which a set of gradually introduced, small phonetic and phonological modifications results eventually in a major structural reanalysis by a new generation of speakers.

45 If the descriptions of explorer Carvalho [1890] can be trusted, the verb system has changed dramatically since the end of the last century. Few of the tenses he listed resemble those in use today even in segmental aspects. That change is continuing at a rapid pace is clear from the surprisingly wide disparity between the tone patterns used by Ruwund youths and those of their parents. The innovations are small in terms of the overall sound of the language, but significant for any analysis. 


\section{Additional Data46}

Noun tonal patterns

- five basic nominal tone patterns (prefixes underlined)

\begin{tabular}{|c|c|c|c|c|}
\hline $\begin{array}{l}\text { yir } \\
\text { 'fields' }\end{array}$ & "ê̂े & $\begin{array}{l}\text { cishipu } \\
\text { 'dry season' }\end{array}$ & $\begin{array}{l}\text { mpàk } \\
\text { 'knife' }\end{array}$ & misîñ \\
\hline$\frac{\text { maj }}{\text { 'dances' }}$ & $\begin{array}{l}\text { mîy } \\
\text { 'thorns' }\end{array}$ & $\begin{array}{l}\text { mulaj } \\
\text { 'sorcerer' }\end{array}$ & $\frac{\text { macìku }}{\text { 'days' }}$ & nñ̂im \\
\hline
\end{tabular}

- long surface root vowels for last three columns 47

\begin{tabular}{|c|c|c|c|}
\hline $\begin{array}{l}\text { ciy } \\
\text { 'door' }\end{array}$ & $\begin{array}{l}\text { cîsu } \\
\text { 'time' }\end{array}$ & $\begin{array}{l}\text { cjirung } \\
\text { "yam" }\end{array}$ & $\begin{array}{l}\text { cirùng } \\
\text { 'basket' }\end{array}$ \\
\hline 'man & $\begin{array}{l}\hat{\mathbf{a} f} f \\
\text { 'cadavers' }\end{array}$ & $\begin{array}{l}\text { kassok } \\
\text { 'ax' }\end{array}$ & $\begin{array}{l}\text { ulààl } \\
\text { "bed' }\end{array}$ \\
\hline
\end{tabular}

- three-syllable nouns

(a)

rutengil (b)

kapàmbamb ïsàlâay,
'scorpion' (d)

'kalimish (e) 'fijbendêl

-Most nouns with second syllable low tones are commonly found with any of the three possible tonal endings illustrated in (b), (c) and (d): 48

uswèral uswèrâl or uswèràl 'laziness'

-All nouns of pattern (e) appear to be borrowings from Swahili, a language with penultimate stress.

46 This section is intended only to provide a context for data included in the body of this paper and should by no means be taken as revealing all important tonal phenomena in the language. The reader is referred to Nash (1992) for a much more thorough presentation, including descriptions of tone in negative and relative verb forms, in forms containing object suffixes, and in predicated nouns.

47 The Ruwund vowels $e$ and $o$ are always long, as are vowels before nasal-initial consonant clusters in spellings.

48 Although dialect differences appear to have been the original source of the variation, contemporary Musumban speakers employ a mix of patterns, the mix usually differing slightly from speaker to speaker. 
- four-syllable nouns:

(a)

cijingidij

'sign' (b)

kasòlikañ

'nepotism' (c)

unsùkùrîil

'sand'

-Most nouns with second syllable low tones are commonly found with either pattern (b) or pattern (c):

yisàwùriil or yisàwùnîil 'manioc fibers'

In some cases, pattern (a) is also a possibility: yisawuriil

Verb tonal patterns

Stems used are -pwiit 'pull', -bacik 'push', and -jikitish 'thank'.

Present Continuous

nipwìtin

/ni-pwi:t-in-a/

'I am pulling'

upwìtin

/wu-pwi:t-in-a/

'yousg are pulling'

ùpwìtin

/wù-pwi:t-in-a/

' $\mathrm{s} / \mathrm{he}$ is pulling'

tupwìtin

/tu-pwi:t-in-a/

'we are pulling'

upwìtinaañ

/wu-pwi:t-in-a-a:ñ-a/49

'youpl are pulling'

àpwìtin

/à-pwi:t-in-a/

'they are pulling' nibàcìkin

'I am pushing'

ubàcìkin

'yousg are pushing'

ùbàcìkin

's/he is pushing'

tubàcìkin

'we are pushing'

ubàcìkinaañ

'youpl are pushing'

àbàcìkin

'they are pushing' nijìkìtìshin

'I am thanking'

ujìkìishin

'yousg are thanking'

ùjìkìtìshin

's/he is thanking'

tujikìtishin

'we are thanking'

ujikìtìshinaañ

'youpl are thanking'

àjìkìishin

'they are thanking'

49 Musumban dialect forms containing pluralizing suffix -aañ employ two copies of the final vowel, one preceding -aan and one following, as is evidenced by such forms as the Habitual Past wapwìtang! aañà /wu-a-pwi:t-ang-à:-a:ñ-à:/ 'youpl used to pull.' 
Present continuous with the prefixes $m u$ - 'him/her' and $k$ a- 'go and':

nimupwìtin

nikamupwìtin ùmùpwìtin

ùkàmùpwìtin
' $\mathrm{I}$ am/he is pulling her'

' $\mathrm{I}$ am/he is going and pulling her'

Narrative

\begin{tabular}{|c|c|c|}
\hline $\begin{array}{l}\text { na!pwiit } \\
\text { /ni-a-pwi:t-a/ } \\
\text { 'I pull' }\end{array}$ & 'I push' & $\begin{array}{l}\text { najikitish } \\
\text { 'I thank' }\end{array}$ \\
\hline $\begin{array}{l}\text { wa!pwiit } \\
\text { /wu-a-pwi:t-a/ } \\
\text { 'yousg pull' }\end{array}$ & $\begin{array}{l}\text { wabàcik } \\
\text { 'yousg push' }\end{array}$ & $\begin{array}{l}\text { wajikitish } \\
\text { 'yousg thank' }\end{array}$ \\
\hline $\begin{array}{l}\text { wàpwiit } \\
\text { /wù-a-pwi:t-a/ } \\
\text { 's/he pulls' }\end{array}$ & $\begin{array}{l}\text { wàbàcik } \\
\text { 's/he pushes' }\end{array}$ & $\begin{array}{l}\text { wàjikitish } \\
\text { 's/he thanks' }\end{array}$ \\
\hline $\begin{array}{l}\text { twa!pwiit } \\
\text { /tu-a-pwi:t-a/ } \\
\text { 'we pull' }\end{array}$ & $\begin{array}{l}\text { twabàcik } \\
\text { ‘we push' }\end{array}$ & $\begin{array}{l}\text { twajikitish } \\
\text { 'we thank' }\end{array}$ \\
\hline $\begin{array}{l}\text { wapwìtinaañ } \\
\text { /wu-a-pwi:t-a-a:ñ-a/ } \\
\text { 'youpl pull' }\end{array}$ & $\begin{array}{l}\text { wabàcikinaañ } \\
\text { ‘youpl push' }\end{array}$ & $\begin{array}{l}\text { wajikitishaañ } \\
\text { 'youpl thank' }\end{array}$ \\
\hline $\begin{array}{l}\text { àpwiit } \\
\text { /à-a-pwi:t-a/ } \\
\text { 'they pull' }\end{array}$ & $\begin{array}{l}\text { àbàcik } \\
\text { 'they push' }\end{array}$ & $\begin{array}{l}\text { àjikitish } \\
\text { 'they thank' }\end{array}$ \\
\hline
\end{tabular}

Narrative with the prefixes $m u$ - 'him/her' and $k a-$ 'go and':

namùpwiit nakàmùpwiit wàmùpwiit

wàkàmùpwiit
'I/he pull(s) her'

'I/he go(es) and pull(s) her' 
Near Past

napwì̀tang

/ni-a-pwi:t-ang-a/

'I pulled'

wapwìtangaañ

'youpl pulled'

wàpwìtang

's/he pulled' nabàcikang

'I pushed'

wabàcikangaañ

'youpl pushed'

wàbàcikang

's/he pushed' najikitishang

'I thanked'

wajikitishangaañ

'youpl thanked'

wàjìkitishang

's/he thanked'

Near Past with the prefixes $m u$ - 'him/her' and $k a-$ 'go and':

namùpwiitang

nakàmùpwiitang wàmùpwiitang

wàkàmùpwiitang
'I/he pulled her'

'I/he went and pulled her'

Recent Past

napwiitin

/ni-a-pwi:t-in-a/

'I pulled'

wapwiitinaañ

'youpl pulled'

wàpwiitin

's/he pulled' nabacikin

'I pushed'

wabacikinaañ

'youpl pushed'

wàbacikin

's/he pushed' najikitishin

'I thanked'

wajıkitishinaañ

'youpl thanked'

wàjikitishin

's/he thanked'

Recent Past with the prefixes mu- 'him/her' and $\mathrm{ka}$ - 'go and':

namupwiitin

nakamupwiitin wàmùpwiitin

wàkàmùpwiitin
'I/he pulled her'

'I/he went and pulled her'

Distant Past

napwiita

/ni-a-pwi:t-à/

'I pulled'

wapwì̀taañà

'youpl pulled'

wapwìta

's/he pulled' nabàcìka

'I pushed'

wabàcìkaañà

'youpl pushed'

wabàcìka

's/he pushed' najìkìtisha

'I thanked'

wajìkìishaañà

'youpl thanked'

wajikìtisha

's/he thanked' 
Distant Past with the prefixes $m u$ - 'him/her' and ka- 'go and':

namupwiita

nakamupwìta wamupwìta

wakamupwìta
'I/he pulled her'

'I/he went and pulled her'

\section{Habitual Past}

napwìtangà

/ni-a-pwi:t-ang-à:/

'I used to pull

wapwìtang!aañà

'youpl used topull'

wapwìtangà

's/he used to pull' nabàcìkangà

'I used to push'

wabàcìkang! aañà

'youpl used to push'

wabàcìkangà

's/he used to push' najìkìtìshangà

'I used to thank'

wajìkìishang! aañà

'youpl used to thank'

wajikitìshangà

's/he used to thank'

Habitual Past with the prefixes $m u$ - 'him/her' and ci- 'still':
namupwìtangà
wamupwìtangà
'I/he used to pull her'
nacimupwì̀tangà
wacimupwìtangà
"I/he was still pulling her" 
Near Future (also used: -fut 'pay' and -non/no:n/ 'take')

$\begin{array}{lll}\begin{array}{l}\text { nikupwiit } \\ \text { /ni-ku-pwi:t-a/ } \\ \text { 'I will pull' }\end{array} & \text { nikubacik } & \text { nikujikitish } \\ \begin{array}{l}\text { ukupwiitaañ } \\ \text { 'youpl will pull' }\end{array} & \begin{array}{l}\text { 'I will push' } \\ \text { 'youpl will push' }\end{array} & \begin{array}{l}\text { ukujikitishaañ } \\ \text { 'youpl will thank' }\end{array} \\ \begin{array}{l}\text { ùkùpwiit } \\ \text { 's/he will pull' }\end{array} & \begin{array}{l}\text { ùkùbacik } \\ \text { 's/he will push' }\end{array} & \begin{array}{l}\text { ùkùjikitish } \\ \text { 's/he will thank' }\end{array} \\ \begin{array}{l}\text { nikufùt 50 } \\ \text { /ni-ku-fut-a/ }\end{array} & \begin{array}{l}\text { nikunon } \\ \text { /ni-ku-no:n-a/ }\end{array} \\ \text { 'I will pay' } & \text { 'I will take' } & \\ \text { ukufùtaañ } & \text { ukunonaañ } & \\ \text { 'youpl will pay' } & \text { 'youpl will take' } \\ \text { ùkufùt51 } & \text { úkúnon } \\ \text { 'she will pay' } & \text { 'she will take' }\end{array}$

Near Future with the prefixes $m u$ - 'him' and ma- 'them':

$\begin{array}{lll}\text { nikumunon } & \text { ùkumunon } 52 & \text { 'I/he will take her' } \\ \text { nikumamunon } & \text { ùkùmamunon } & \text { 'I/he will take them from her' } \\ \text { nikumufùt } & \text { ùkumufùt } & \text { 'I/he will pay her' } \\ \text { nikumamufùt } & \text { ùkùmamufùt } & \text { 'I/he will pay her for them' }\end{array}$

50 Monomoraic stems are low-toned in future tenses.

51 As described in footnote \#34, the underlying low of subject prefix $u$ - would normally spread to $k u$ - in this form, since both syllables belong to the same metric foot. Spread in the future tenses is blocked, however, in cases where an OCP violation would result.

52 See footnote \#34 for a brief explanation of prefixal low spread in future tenses. 


\section{REFERENCES}

Bastin, Yvonne. 1978. "Les Langues Bantoues.” In D. Barreteau (eds.), Inventaire des Etudes Linguistiques, Paris: Conseil International de la Langue Française.

Botne, Robert. 1991. "Verbal Prosody in Ciruri." Journal of African Languages and Linguistics 12:107-142.

Carvalho, Henrique Augusto Dias de. 1890. Methodo Pratico Para Fallar a Lingua da Lunda Contendo Narrações Historicas dos Diversos Povos. Lisbon: Imprenza Nacional.

Clark, Mary. 1989. The Tonal System of Igbo. Dordrecht: Foris Publications.

Goldsmith, J., K. Peterson, and J. Drogo. 1989. "Tone and accent in the Xhosa verbal system." In P. Newman and R. Botne (eds.), Current Approaches to African Linguistics 5, Dordrecht: Foris Publications.

Guthrie, M. 1948. The Classification of the Bantu Languages. London: Oxford University Press.

Guthrie, M. 1971. Comparative Bantu. Farnborough, Hants., England: Gregg International Publishers, Ltd.

Maddieson, Ian. 1976. "Tone Reversal in Ciluba-A New Theory." In L. Hyman (ed.), Studies in Bantu Tonology. Southern California Occasional Papers in Linguistics 3.

Nash, Jay. 1992. “Aspects of Ruwund Grammar." Ph.D dissertation, University of Illinois, Urbana-Champaign.

Pulleyblank, D. 1986. Tone in Lexical Phonology. Boston: D. Reidel.

Jay Nash

c/o Africa Region

Catholic Relief Services

209 W. Fayette Street

Baltimore, MD 21201-3443
[Received June 28, 1990; accepted December 8, 1992; final version received June 21,1993 ] 